\author{
Melina Moleskis
}

Miguel Ángel Canela 


\title{
CROWDFUNDING SUCCESS: THE CASE OF KIVA.ORG
}

\author{
Melina Moleskis ${ }^{1}$ \\ Miguel Ángel Canela ${ }^{2}$
}

\begin{abstract}
Crowdfunding is the process of raising money to fund a project or business venture through numerous investors and via an Internet platform. The objective of this report is to examine the growing phenomenon of crowdfunding as an alternative method for raising finance and the factors that lie behind its success. The analysis focuses on Kiva.org, one of the most successful crowdfunding platforms in the world.
\end{abstract}

Keywords: crowdfunding; Kiva; funding strategy; online platforms.

\footnotetext{
${ }^{1}$ PhD candidate, IESE. MMoleskis@iese.edu.

${ }^{2}$ Visiting Professor, Managerial Decision Sciences, IESE. MCanela@iese.edu.
} 


\section{CROWDFUNDING SUCCESS: THE CASE OF KIVA.ORG}

\section{Table of Contents}

1. INTRODUCTION 2

1.1 The Phenomenon of Crowdfunding 2

1.2 Kiva.org 2

1.3 Crowdfunding at Kiva 3

2. THE KIVA WORLD 3

2.1 "Objects" in the Kiva World 3

2.2 Funding and Repayment Process 5

2.3 Risks to Repayment 6

3. METHODOLOGY 7

$\begin{array}{ll}3.1 \text { Capturing the Data } & 7\end{array}$

3.2 Processing the Data 9

3.3 Methods of Analysis 11

4. THE LENDERS 11

4.1 Kiva Lenders 11

4.2 Description of the Lender Population 11

$\begin{array}{ll}4.3 \text { Lending Activity } & 13\end{array}$

5. THE PARTNERS 14

5.1 Kiva Field Partners 14

5.2 Description of the Partner Population $\quad 15$

5.3 Partner Risk and Interest Rate Policy 16

6. THE LOANS 17

$\begin{array}{ll}6.1 \text { Kiva Loans } & 17\end{array}$

$\begin{array}{ll}6.2 \text { Description of the Loan Population } & 18\end{array}$

6.3 Loan Status: Success or Failure 22

7. THE DRIVERS OF SUCCESS OR FAILURE IN FUNDRAISING 25

$\begin{array}{ll}7.1 \text { Expiration } & 25\end{array}$

7.2 Defaults 29

7.3 Refunds 32

8. CONCLUSIONS AND FURTHER STUDY 32

9. REFERENCES 34 


\section{Introduction}

\subsection{The Phenomenon of Crowdfunding}

Crowdfunding is the process of raising money to fund a project or business venture through numerous investors and via an Internet platform. Online crowdfunding is a relatively new phenomenon that has increased the number of ways in which consumers, entrepreneurs and organizations can access capital. In principle, crowdfunding platforms are designed to put individuals who are willing to lend or invest their money in contact with other individuals, projects or businesses that need financial support.

Crowdfunding as a concept predates the Internet since projects such as the Statue of Liberty raised funds from a large number of donors. In that case, the donors were the people of France, enticed through a large number of fundraising events and auctions, back in 1882. Crowdfunding gained traction, however, after the launch of the Internet as a consequence of global connectivity, easy access to online content and increased awareness of financing needs. In 2015, crowdfunding websites helped companies and individuals worldwide raise $\$ 34$ billion from members of the public (Massolution, 2015). Moreover, the industry is projected to have raised \$1 trillion in 2025.

The objective of this report is to examine more closely the new and important phenomenon of crowdfunding as an alternative method for raising finance and the factors that lie behind its success. This report serves as the foreground to our academic work on crowdfunding, which seeks to identify theoretically and empirically the factors behind crowdfunding's success, in the contexts of both entrepreneurship and charity (Moleskis, Alegre and Canela, 2016). We focus our analysis on Kiva.org, one of the most successful crowdfunding platforms in the world.

\subsection{Kiva.org}

Founded in 2005, Kiva.org is one of the world's largest online crowdfunding platforms where people can lend money to underserved entrepreneurs across the globe. With the mission of "connecting people through lending to alleviate poverty," Kiva strives to provide safe and affordable access to capital in regions where traditional banking services fail to do so, thereby enabling people to create opportunities for themselves and their families by becoming entrepreneurs.

In essence, Kiva acts as an online bridge between borrowers and lenders. The profiles of people from developing countries who are in search of microcredit are posted on Kiva's platform. Lenders browse the different profiles and invest money in their preferred projects, according to the characteristics of the loan request and the borrower. For instance, the country of origin and gender of the borrower might attract more or less funding depending on the fit with the lender's preferences, as might the intended use of the loan and the repayment term, which are some of the loan characteristics. Kiva itself does not collect any interest on the loans it facilitates, nor do Kiva lenders gain interest on the loans. Borrowers, however, pay interest to the intermediaries of the financing process, referred to as field partners, who are essentially the ones that bear most of the risk.

Based on data collected in March 2015, Kiva is active in 83 developing countries and collaborates with 304 field partners. This collaboration with field partners is a special trait of Kiva, compared to many other lending platforms. The field partners' role is to facilitate the process by establishing a local presence and advancing the money to the borrowers prior to posting the loan request on the Kiva platform, so as to give the borrowers a head start in their entrepreneurial venture. To date, the organization has crowdfunded more than 1 million loans, totaling more than $\$ 800$ million, at a repayment rate of $98.4 \%$. 


\subsection{Crowdfunding at Kiva}

Kiva allows microfinance institutions, social businesses, schools and nonprofit organizations around the world, which it calls field partners, to post profiles of qualified local entrepreneurs on its website. The process begins when a person in a developing country approaches a field partner to ask for a loan, or vice versa. The partner then evaluates the profile of the entrepreneur and accepts or rejects the application. If the application is accepted, the partner uploads the borrower's profile onto the Kiva platform, including a photograph of the borrower, the description of the intended use for the loan and the amount requested. Loan requests are posted for a period of 30 days only, during which time lenders may respond to the request for funding. Eventually, those requests that do not attract the requested amount are declared to have expired.

On the investor side, lenders browse and choose an entrepreneur they wish to fund. Kiva lenders may select and decide to fund any of the available loans posted on the platform. The minimum funding amount is $\$ 25$ and, on most occasions, a loan is funded by several lenders. The lenders then transfer their funds to Kiva through a special service on PayPal, which waives its transaction fee and thereby spares lenders any costs other than funding. Upon receiving money from various lenders, Kiva aggregates the capital and transfers it to the appropriate field partner.

Once a project has been funded, the repayment phase starts. Repayment may occur at different intervals and over varying time periods, according to the agreement between the entrepreneur and the field partner. The entrepreneur returns the borrowed amount plus interest to the partner who, in turn, returns the invested money to the lender but keeps the interest. In that way, the lender recovers the money invested and can decide to withdraw the money or reinvest it in other Kiva projects.

\section{The Kiva World}

\section{1 "Objects" in the Kiva World}

The key "objects" in the Kiva world are the borrower, the lender and the partner, all of whom are connected to the loan. A borrower is someone who has requested a loan. Borrowers are often referred to as "businesses" or "entrepreneurs" in order to emphasize the entrepreneurial spirit of these individuals who work to make a difference in their lives. A loan may have more than one borrower and, in this case, the loan is considered a group loan. Information about the borrower includes gender and country of origin.

A lender is a user registered on the Kiva website for the purposes of lending money and participating in the community. Some lenders have public profiles, known as lender pages, on the Kiva website, where they can share details about their activities and mission. Most lenders, however, refrain from displaying their public information and are referred to as "anonymous." In addition, not all lenders are active in the sense of having provided a loan. Moreover, lenders can coordinate their activity on Kiva through lending teams. These teams are usually formed around a common interest (sometimes related to lending, sometimes not) or may represent real-world groups outside Kiva such as a church or a class of students. Examples include the Kiva Christians and Harvard University teams. Teams also have profile information, similar to lenders, where they post a team photo and explain why the team members have come together to provide a loan. Lending teams have been described extensively elsewhere (e.g., Hartley, 2010). More information can be found at http://www.kiva.org/teams. 
A partner, or Kiva field partner, is usually a microfinance institution with which Kiva works to find and fund loans. Every loan at Kiva is offered by a partner to a borrower, and the partner works with Kiva to get funding for that loan from lenders. The association between a loan and a partner is of great importance since the risk pertaining to a loan correlates closely to the reputation of the partner. This is why Kiva tries to assign a risk rating to every partner, when possible, following an annual due diligence process.

The loan is the most important data object at Kiva since facilitating loans that change lives is at the heart of Kiva's mission. Most other objects are in some way related to a loan. Every loan has a journal where Kiva or a partner can provide updates. Each loan listing has information regarding the key details about the loan, such as the name and photo of the borrower, the loan amount, and the intended use of the loan. Furthermore, in the Kiva world, the status of a loan is an especially important concept. At a particular point in time, the loan's status may be fundraising, funded, in repayment, paid, expired, defaulted or refunded.

- Fundraising: The loan request is in the fundraising process if the loan has not yet been fully funded and the 30 days since its posting date have not passed. Such loans are typically advertised on the Kiva home page, and lenders can only respond to requests for loans that have fundraising status. The field funded amount shows the amount of the loan that has been provided by Kiva lenders. When the funded amount becomes equal to the loan amount then the loan moves to funded status, soon followed by in repayment. The basket amount is the amount of the loan that lenders have put in their online shopping baskets but has not yet been confirmed as lent. Where the sum of the funded amount and the basket amount exceed or are equal to the loan amount the loan becomes unavailable to other lenders through it is still listed as having fundraising status. The fundraising may last for up to 30 days maximum.

- Funded: When the loan request has been completely funded, it is no longer open to new loans by lenders. The field funded date shows the exact time at which the loan has been fully funded on Kiva. Once the loan moves to funded status and, in the unusual case where disbursal has not already taken place, the loan may become disbursed to the borrower.

- In repayment: Once the loan has been funded and the money disbursed to the borrowers, then the loan moves to the repayment phase, whereby entrepreneurs begin making payments to the field partner. Loans with this status may have journal updates, and those who have contributed to this loan will get repayments when the borrower's payments are reconciled with Kiva.

- Paid: Once the repayments are completed, the loan is marked as having been paid back in full by the borrower. At this stage, the repayments have been distributed back to the lenders and the loan is closed to most new activity on Kiva.

- Expired: If a loan is not fully funded within 30 days of being listed on the website then the loan expires. This means that the loan profile remains on the site but shows up as expired, all lenders who have chipped in to fund the loan receive a refund, and the field partner administering the loan does not receive any of the funds.

- Defaulted: Occasionally, a borrower or a field partner may fail to make payments on a loan, to the field partner or to Kiva respectively. To mitigate the risk, each borrower is screened by a local Kiva field partner before their application is posted on the Kiva 
website. The field partner looks at a variety of factors (such as loan history, village or group reputation and loan purpose) before deeming a borrower to be creditworthy. Despite these precautions, a variety of factors can result in borrowers defaulting. These include business issues such as crop failure, health issues such as malaria and other issues such as theft, overindebtedness and civil disturbances. With respect to the partner, a default may be the result of bankruptcy, fraud or operational difficulties. When repayment difficulties crop up, the loan first becomes delinquent and continues to have the in repayment status. If a loan remains delinquent for six months after the end of the loan payment schedule, then the loan becomes defaulted. Defaulted loans constitute a financial loss to the lenders who financed that loan.

- Refunded: On rare occasions, Kiva may need to refund the funded portion of the loan to lenders after the loan has been funded partially or fully or even during repayment. There are many reasons why a loan can be refunded but usually it is because of an error with the posting or because the loan itself has been found to violate Kiva's policy.

\subsection{Funding and Repayment Process}

Once posted on the Kiva website, a loan enters its fundraising phase. From there, it can either be fully funded or expired after not receiving the whole amount of funding requested within 30 days or the process can be stopped and the money lent refunded to the investors. If the loan is successfully funded, it moves to repayment. Delinquency can occur while the loan is in the repayment phase and for up to six months before the loan is declared defaulted. Delinquency acts as an early warning sign of possible default but this does not affect the status of the loan as such. Again, at this stage the loan may be refunded. Finally, if repayment is completed successfully, the loan gains the status of paid. Otherwise, the borrower may default on the repayments, rendering the status of the loan defaulted.

Below is a flowchart of showing the stages of a loan's status. A successful procedure is shown in bold letters and arrows, whereas lack of success can be in the form of expiration, default or refunds and this is depicted in the rest of the boxes.

\section{Figure 2.2.1}

Flowchart of the funding process

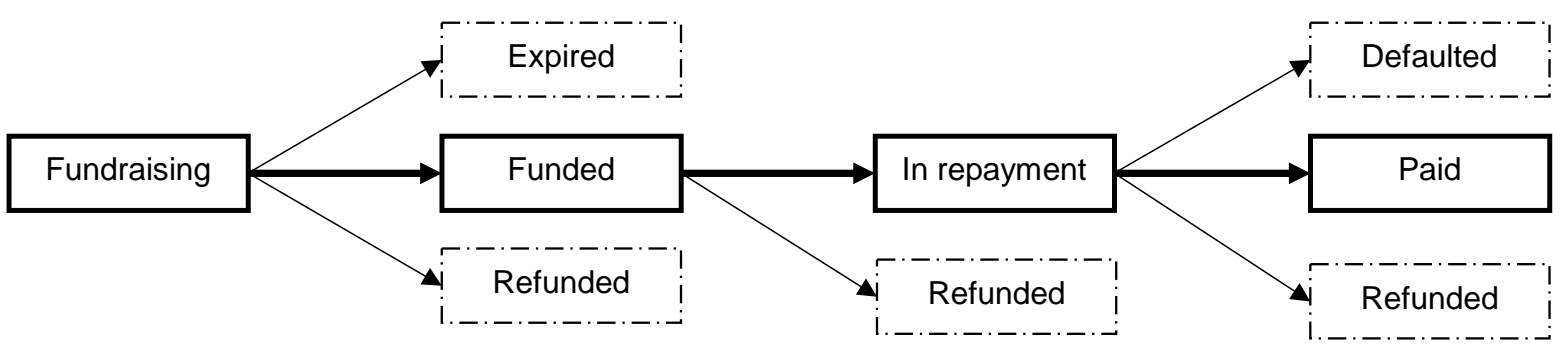

The repayment period starts as soon as the loan becomes fully funded. When a field partner uploads an entrepreneur's loan request to Kiva, they also include the anticipated repayment dates for the loan. This repayment schedule can be monthly, once at the end of the loan term, or any other pattern that reflects most accurately the way that the entrepreneur has agreed to make repayments. Kiva reports the list of payments that have been made by the borrower and reconciled with Kiva's accounting system. A payment usually has an amount in U.S. dollars, a local amount in the disbursal currency, a processed date (the approximate date on which the borrower paid the partner), a settlement date (the date on which funds for payment from the partner were reconciled 
by Kiva) and, possibly, some comments. Scheduled payments are the payments (in U.S. dollars) that are due to lenders and include the dates when lenders can expect a repayment, provided the loan is not delinquent. Note that scheduled payments can be understood as the loan schedule from the lenders' point of view. In addition, journal totals show the number of total journal entries for the loan as well as the number of automated entries. In principle, nonautomated entries are more interesting as they can reveal something unusual about a loan.

Field partners have until the end of the month in which each anticipated repayment is due to let Kiva know whether or not they have actually collected the repayment. Once Kiva has this information, Kiva generates a bill to charge the field partner for all the repayments they collected that month. Kiva works on a net billing system. This means that, for any given month, Kiva subtracts the amount of repayments that a field partner owes to Kiva lenders from the amount that a field partner fundraises for entrepreneurs on Kiva. If the balance is positive, that means that the partner has raised more than they need to repay, and Kiva uses those funds to credit the lender account with the repayments due to them. If the balance is negative, then the partner has to send a payment to Kiva for the balance. As soon as Kiva receives that payment, the organization uses those funds to credit the lender account with the repayments due. Once the repayment is made to the lender, the lender may choose to relend the funds, donate them to Kiva's operating expenses, purchase a gift certificate or withdraw them to be credited to the lender's PayPal account.

In summary, Figure 2.2.2 depicts a simplified version of the repayment process as money changes hands from the borrower to the partner, through Kiva's net billing system, and finally reaches the hands of the lender in the form of U.S. dollars.

\section{Figure 2.2.2}

Flowchart of the repayment process

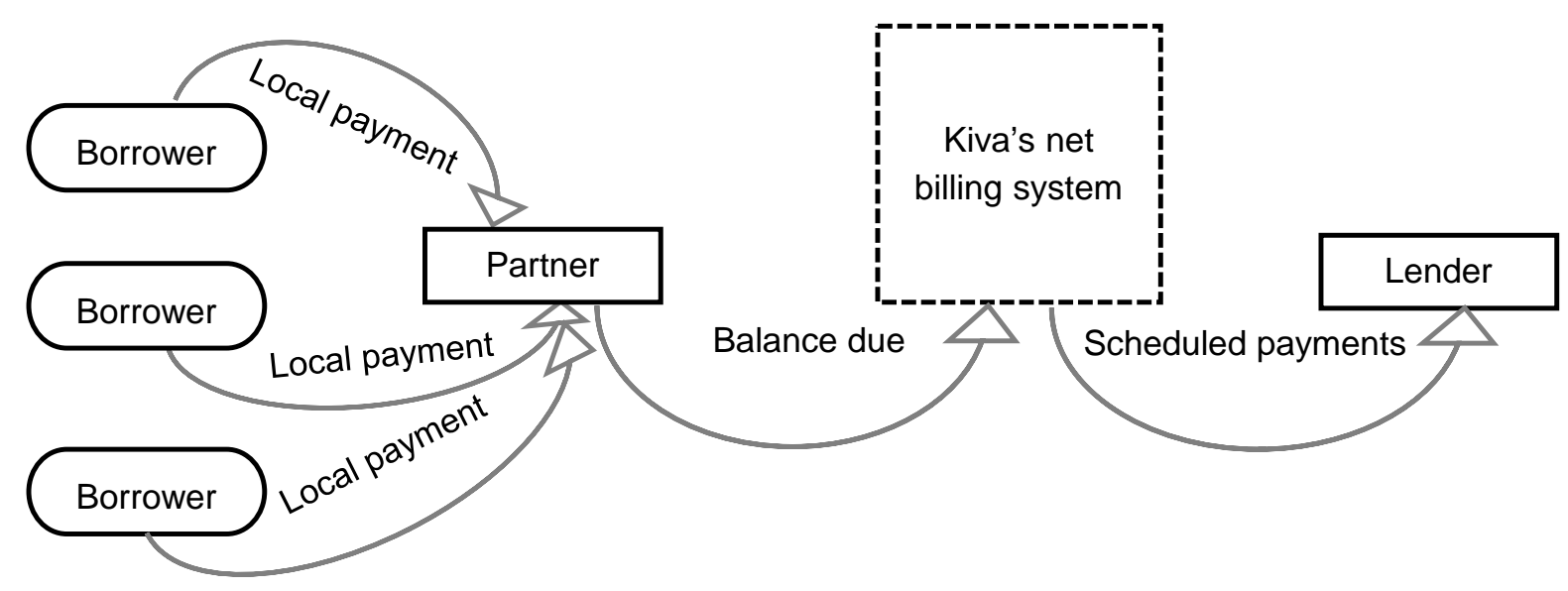

\subsection{Risks to Repayment}

There are three main risks affecting the likelihood that lenders will get their money back. First, there is a risk associated with the borrowers. Borrowers are often able to pay the loan officer the full amount due, on time, without any issues. On occasion, a borrower or field partner may be late with payments. This will affect the delinquency rate of the field partner. Kiva defines the delinquency rate as the amount of late payments divided by the total outstanding principal 
balance Kiva has with the partner. Arrears can result from late repayments from Kiva borrowers as well as delayed payments from the field partner. For loans that are delinquent at the end of a loan term, Kiva allows the field partner six additional months to attempt to collection the money before giving the loan defaulted status. The default rate is the percentage of ended loans (no longer being paid back) that have failed to be repaid (measured in dollar volume, not units).

Second, while working with field partners increases the likelihood that the loan will be used effectively and repaid, new institutional risks are introduced by the presence of third parties. Even if a Kiva borrower is able to repay, Kiva lenders could still lose principal due to field partner issues such as bankruptcy, fraud or operational difficulties. For example, the field partner may go out of business and be unable to collect the loan, staff members at the field partner may embezzle funds or the partner may have cash flow or other challenges that could prevent repayment.

Third, there is also currency exchange risk. When funds are being lent across national boundaries, there is an implicit risk with currency values changing relative to one another. The local currency in the partner's country of operation may, for many reasons, lose some of its value relative to the U.S. dollar, thus requiring the field partner to use more local currency to reimburse Kiva (since Kiva's working currency is the U.S. dollar). For currency exchange, the liability can be shared, rest fully on the partner, or be nonexistent if the currency is locked to the U.S. dollar. If currency exchange loss is shared between a partner and the lender, then information about the loan includes the currency exchange coverage rate and the currency exchange loss amount. The latter represents the amount in U.S. dollars lost by the lender due to fluctuations in the value of the local currency against the U.S. dollar. This will result in the paid amount of the loan being less than the full loan amount even when the status of the loan is listed as paid.

\section{Methodology}

\subsection{Capturing the Data}

The data used in this study come from two separate data snapshots of the Kiva Application Programming Interface (Kiva API), retrieved from build.kiva.org. Information on lenders, borrowers and loans was captured through a snapshot on March 9, 2015, while information on partners was collected separately through another snapshot one week later.

"Kiva API" refers to "the set of web services provided by Kiva at api.kivaws.org for purposes of programmatically accessing data or information in or through the Kiva microlending platform." A snapshot contains the memory state of the database at the moment it is captured, including information about all existing objects, and about references between objects. The data came in packets of 500 instances, in XML format. The XML documents were parsed and imported into R data frames using the XML package (Nolan and Lang, 2014). These data frames were then merged. The data amount to approximately 850,000 loans and 1.6 million lenders. Descriptive information about the loans and lenders, restricted to one of the XML documents, is shown in Tables 3.1.1 and 3.1.2 below. 


\section{Table 3.1.1}

Field names and descriptions of borrower and loan characteristics

\begin{tabular}{|c|c|}
\hline Field name & Field description \\
\hline \multicolumn{2}{|l|}{ Borrower characteristics } \\
\hline gender & Gender of main borrower: male or female. \\
\hline country_code & $\begin{array}{l}\text { Country of borrower in two-digit ISO country codes. There are } 90 \text { countries listed } \\
\text { in the database. }\end{array}$ \\
\hline \multicolumn{2}{|l|}{ Loan characteristics } \\
\hline id & Identification number of the loan. This is unique for each loan. \\
\hline group & $\begin{array}{l}\text { Dummy for a loan being taken by more than one person. Some } 14 \% \text { of loan } \\
\text { requests are from groups. }\end{array}$ \\
\hline posted_date & Date the loan request was posted on Kiva's website. \\
\hline disbursal_date & Date the borrower received funding from the field partner. \\
\hline sector & $\begin{array}{l}\text { Agriculture, the arts, clothing, construction, education, entertainment, food, } \\
\text { health, housing, manufacturing, personal use, retail, services, transportation, or } \\
\text { wholesale. }\end{array}$ \\
\hline activity & Specific activity per sector, out of 149. \\
\hline use & One-sentence description of the intended use of the loan. \\
\hline description & $\begin{array}{l}\text { Some paragraphs describing the borrower, their background and the intended } \\
\text { use of the loan. }\end{array}$ \\
\hline tags & Words assigned to loan requests. \\
\hline attributes & $\begin{array}{l}\text { Phrases used to describe loans: green, higher education, Islamic finance, youth, } \\
\text { start-up, water and sanitation, vulnerable groups, fair trade, rural exclusion, } \\
\text { mobile technology, underfunded areas, conflict zones, job creation, growing } \\
\text { businesses, disaster recovery, and innovative loans. }\end{array}$ \\
\hline loan_amount & The amount requested. It varies from $\$ 25$ to $\$ 100,000$, with a mean of $\$ 854$. \\
\hline funded_amount & $\begin{array}{l}\text { The amount of the loan already funded. It varies from } \$ 0 \text { to } \$ 100,000 \text {, with a } \\
\text { mean of } \$ 825 \text {. }\end{array}$ \\
\hline paid_amount & The amount of the loan repaid by the borrower to the lender. \\
\hline repayment_interval & $\begin{array}{l}\text { Frequency of repayments: at the end of term, irregularly or monthly. Most loans } \\
\text { are scheduled for monthly repayments. }\end{array}$ \\
\hline repayment_term & Period of time granted for repayment, in months. \\
\hline bonus_credit_eligibility & Credit rating assigned to the loan by the field partner: either 0 or 1. \\
\hline delinquent & $\begin{array}{l}\text { Dummy for delinquency. Delinquency occurs when the due date for the } \\
\text { repayment has passed and the funds have not been returned to Kiva lenders. } \\
\text { This can be because either the borrower or field partner has fallen behind in } \\
\text { repayments. }\end{array}$ \\
\hline partner_id & Identification of the field partner: numeric. \\
\hline status & Funded, fundraising, expired, paid, in repayment, refunded or defaulted. \\
\hline
\end{tabular}




\section{Table 3.1.2}

Field names and descriptions of lender characteristics

\begin{tabular}{ll}
\hline Field name & Field description \\
\hline lender_id & Identification consisting of a name, such as Jessica, plus a number, as in \\
jessica2749, to avoid repetition. Most are English names. \\
Country_code \\
are concentrated in 10 countries, with the United States at the top. \\
This denotes the year of affiliation. The first lenders entered in January 2006 \\
and their total had risen to $1,630,082$ by March 2015. \\
occupation \\
In 483,612 cases, lenders report their occupation. \\
Indicates the activity of lenders. For 640,729 lenders (39.3\%), the number of \\
loans is zero, which means that they have been inactive. Some $84.7 \%$ of the \\
cases do not go beyond five loans. \\
invitee_count
\end{tabular}

Descriptive information about the partners is shown in Table 3.1.3 below.

\section{Table 3.1.3}

Field names and descriptions of partner characteristics

\begin{tabular}{|c|c|}
\hline Field name & Field description \\
\hline partner_id & $\begin{array}{l}\text { Identification of the field partner: numeric. This field corresponds to partner_id } \\
\text { in the loan data. }\end{array}$ \\
\hline name & Official name of the organizations partnering with Kiva. \\
\hline rating & $\begin{array}{l}\text { Risk rating of the partner, as assigned by Kiva, reflecting the risk of institutional } \\
\text { default. It is based on a star system, with five stars indicating the lowest risk } \\
\text { and one star indicating the highest risk. }\end{array}$ \\
\hline delinq & $\begin{array}{l}\text { The delinquency rate is the amount of late payments divided by the total } \\
\text { outstanding principal balance that Kiva has with the partner. Arrears can result } \\
\text { from late repayments from Kiva borrowers as well as delayed payments from } \\
\text { the partner. The rate is given as a percentage, with a mean of } 9.74 \% \text {. }\end{array}$ \\
\hline default & $\begin{array}{l}\text { The default rate is the percentage of ended loans (no longer being paid back), } \\
\text { which have failed to be repaid (after having being delinquent for more than six } \\
\text { months). The rate is given as a percentage, with a mean of } 3.61 \% \text {. }\end{array}$ \\
\hline charges & Dummy for the partner charging interest. Charges occur in $99 \%$ of the cases. \\
\hline
\end{tabular}

\subsection{Processing the Data}

In the original data set, there are 849,980 loans. Not all of these loan entries, however, have complete data. Hence, the first issue to tackle is that of missing data. Data are missing from fields such as repayment term $(2,235)$, status $(3)$, posted date $(17,130)$, disbursal date $(1,633)$ and use (13). In total, 17,151 loans have key data missing.

Moreover, upon inspection of the original data set, we noticed some abnormalities in the status classifications. The full list of classes comprises defaulted, deleted, expired, funded, fundraising, in repayment, inactive, inactive-expired, issue, paid, refunded and reviewed. Abnormalities occur with the inactive, inactive expired, issue and reviewed classes and, to our knowledge, Kiva offers 
no clear definition of these. Moreover, these entries can be found only in the early days of Kiva's operations. In particular, issue, reviewed, deleted, inactive and inactive-expired loans are loans for which there is a requested amount but the funded amount and lender count are zero, and the posted date is missing. Actually, because of the missing entries, once rows with missing data are dropped, the undefined loan statuses are eliminated.

Furthermore, we note that there are some loans that have been listed multiple times, with between one and four surplus entries. For these rows, the loan identification number is the same and, since the ID is unique for each loan, these entries appear to be surplus in the sense that they do not add new information and need to be removed from the data set. In fact, 77,354 loans have been listed twice, 23,113 loans have three entries, 3,102 loans have four identical entries and 46 loans have five entries. In total, 133,070 of the observations are surplus. Furthermore, although the data range from 2005 to 2015, multiple entries mostly occur in the period from 2007 to 2011, as can be seen in Figure 3.2.1. Duplications start appearing in 2005 but do not exceed 30 in that year. In 2007 surplus entries rise close to 8,800 and in 2008 the number doubles to 17,100. From 2008 to 2011 the number of surplus listings per year rapidly increases, reaching 38,143 in 2011. Thereafter, the number falls considerably to around 200 per year in 2013 and 2014.

\section{Figure 3.2.1}

Surplus listings

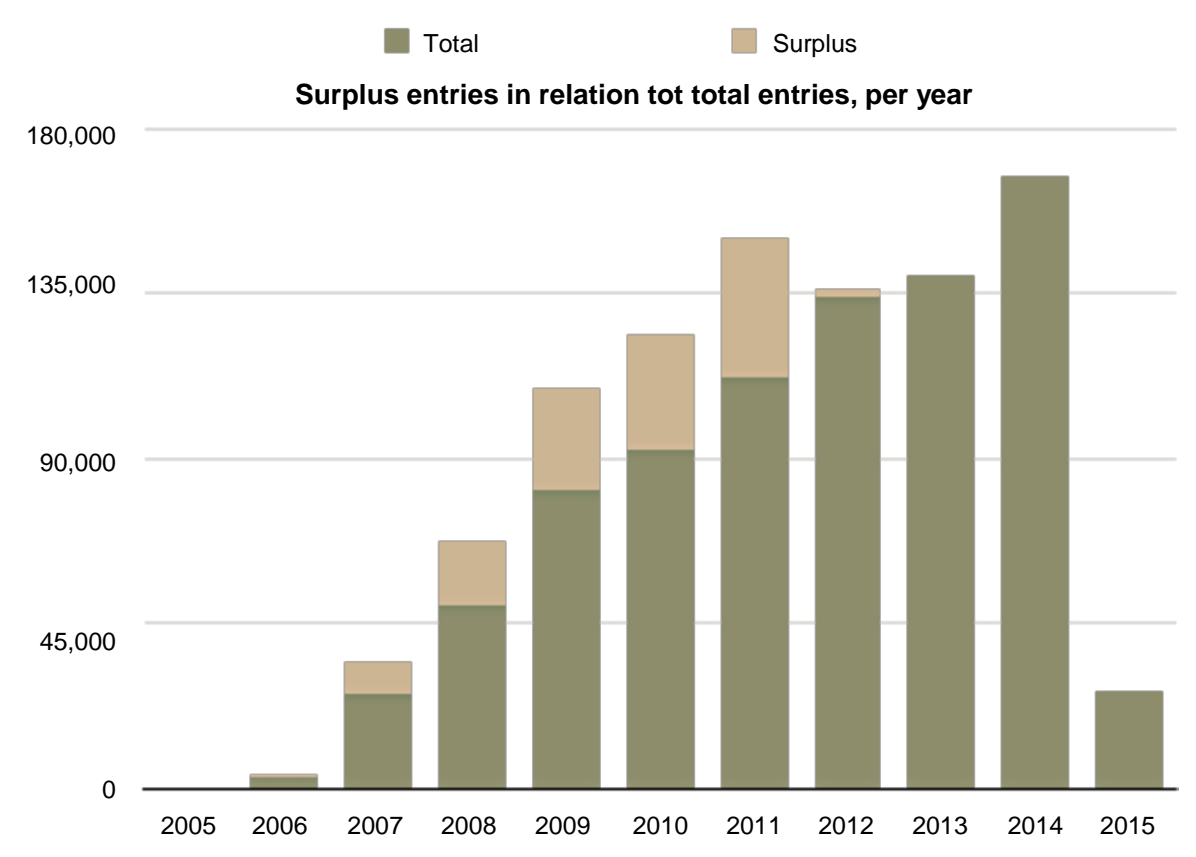

It is also interesting to note that 121,822 of these surplus entries are successful loans that have reached paid status, having progressed seamlessly through the Kiva process up to and including the repayment phase. Dropping these surplus listings from the original data set would leave 716,910 loans.

In cleaning the original data set, we account for both missing data and duplicated entries. This leaves 705,611 loans, which are used to perform the analysis. We then merge the loan data frames with the partner data frame by using the field partner_id as the common field. This allows us to incorporate partner characteristics into our analysis. Moreover, we have introduced another explanatory variable by grouping the countries into eight geographical regions - namely, North America, Central America, South America, Africa, Eastern Europe, the Middle East, Asia and Oceania. 


\subsection{Methods of Analysis}

We start our analysis with descriptive statistics, in order to understand better the variables within the vast data set. Since the data set represents the entire population (up to March 9, 2015) of the loans administered through Kiva and not just a sample, we use descriptive statistics to understand the Kiva world in its entirety, without having to extrapolate our results. In particular, we use univariate analysis to examine across our main variables, looking at the distribution, the central tendency (e.g., the mean), and the dispersion (e.g., the standard deviation and range). Moreover, we use cross-tabulation in order to capture the likelihood of occurrence between two events - for example, the professional occupation of lenders and how active they are on the Kiva platform. We also carry out a text analysis to identify the most frequent words used in the use field, a field that gives a short description of the purpose of the loan, in an attempt to decipher borrower intentions and the language used on Kiva.

\section{The Lenders}

\subsection{Kiva Lenders}

Lenders on Kiva may choose to share their information publicly. Unfortunately, however, not many of them do so, which results in a lot of missing information in this part of the data set. The snapshot of March 9, 2015, contains 1,631 pages, with 100 lenders per page, which gives us data on 1,630,083 lenders. Nevertheless, this database has been contaminated by a "prescription-free" and "best pharmacy" direct mail campaign. Filtering out the spurious data, we are left with $1,629,518$ records.

Every lender is identified by the attribute lender_id, which is a name, such as Jessica, plus a number, as in jessica2749, to avoid repetition. The ID is missing in nine cases. Most are English names, in accordance with the distribution across countries. (See Table 4.2.1 below.) The most frequent name is Christopher $(31,639)$, followed by David $(15,288)$, Michael $(14,451)$ etc., with the expected power-law distribution.

Other attributes we examine in this data set are: country_code (the two-digit ISO code), member_since, occupation, loan_count and invitee_count. The data are quite sparse, with a high proportion of missing values in some attributes, as discussed below.

\subsection{Description of the Lender Population}

The country identifier is missing in 931,091 cases, which in our analysis are regarded as missing at random. There are 234 countries identified but $90 \%$ of the cases are concentrated in 10 countries, as reported in Table 4.2.1. Four English-speaking countries take the top places, with the United States the leader by far. So, from the lenders' point of view, the Kiva world does not look truly global. 


\section{Table 4.2.1}

Lenders by country

\begin{tabular}{lrlr}
\hline U.S. & 455,088 & Netherlands & 10,051 \\
Canada & 65,736 & Sweden & 8,936 \\
Australia & 32,632 & Norway & 6,535 \\
U.K. & 26,137 & France & 5,272 \\
Germany & 14,142 & India & 4,812 \\
\hline
\end{tabular}

Furthermore, for the year of affiliation, which is probably recorded automatically, there is only one missing value. The first lenders enter in January 1, 2006. The evolution of the affiliation can be followed in Table 4.2.2. In the year 2015, it can be expected to be very high, since the data cover just until March. The quality of the lender database seems to be deteriorating, as seen in the percentage of lenders that provide information about themselves. In the table, the increasing number of lenders not declaring their country illustrates this.

\section{Table 4.2.2}

Membership by year

\begin{tabular}{rrrlrr}
\hline Year & New lenders & Country missing & Year & New lenders & Country missing \\
\hline 2006 & 19,035 & 3,303 & 2011 & 180,580 & 92,405 \\
2007 & 159,173 & 44,609 & 2012 & 178,369 & 81,885 \\
2008 & 173,654 & 67,677 & 2013 & 122,505 & 95,209 \\
2009 & 201,337 & 88,720 & 2014 & 267,034 & 217,877 \\
2010 & 175,086 & 94,626 & 2015 (to March) & 153,094 & 144,779 \\
\hline
\end{tabular}

Lenders also disclose their professional occupation. The three text attributes with which the lenders can describe themselves are mostly empty. Occupation is missing in 1,146,462 cases, occupational information in 1,511,929 cases, and lending motivation in 1,472,969 cases. Among the 483,612 lenders reporting an occupation, the top lender category is that of student (15.7\%), followed by teaching (professors/teachers). Table 4.2.3 shows some data for the most common occupations, by year.

Table 4.2.3

Occupation by year

\begin{tabular}{lrrrrrr}
\hline Year & Student & Teaching & Retired & Manager & Engineer & Consultant \\
\hline 2006 & 1,315 & 1,105 & 941 & 514 & 693 & 440 \\
2007 & 13,219 & 10,334 & 8,421 & 5,116 & 4,372 & 3,497 \\
2008 & 17,468 & 10,337 & 6,620 & 4,969 & 4,367 & 3,432 \\
2009 & 23,458 & 11,308 & 5,757 & 5,012 & 5,274 & 3,670 \\
2010 & 15,337 & 6,521 & 3,066 & 2,895 & 2,969 & 1,931 \\
2011 & 2,519 & 870 & 464 & 564 & 617 & 365 \\
2012 & 1,706 & 520 & 280 & 410 & 378 & 234 \\
2013 & 583 & 255 & 134 & 185 & 182 & 117 \\
2014 & 450 & 165 & 105 & 432 & 230 & 128 \\
2015 & 64 & 40 & 7 & 44 & 21 & 12 \\
\hline Total & $\mathbf{7 6 , 1 1 9}$ & $\mathbf{4 1 , 1 5 5}$ & $\mathbf{2 5 , 7 9 5}$ & $\mathbf{2 0 , 1 4 1}$ & $\mathbf{1 9 , 1 0 3}$ & $\mathbf{1 3 , 8 5 6}$ \\
\hline
\end{tabular}




\subsection{Lending Activity}

The account of lending activity is complete, since it is recorded automatically. Interestingly, for 640,729 lenders (39.3\%), the number of loans is zero, which means that they have been inactive all the time. The distribution of the number of loans has also a power-law profile. On the right tail, the maximum is 128,128 , and there are only three lenders with more than 100,000 loans. The left tail is shown in detail in Table 4.3.1, which shows that most of the registered lenders do not engage in much activity, or the activity is occasional. Some $84.7 \%$ of the cases do not go beyond five loans. Also, as seen in Table 4.3.1, there seems to be an overall upward trend in the percentage of inactivity.

\section{Table 4.3.1}

Number of loans

\begin{tabular}{cccc}
\hline Loans & Number of cases & Loans & Number of cases \\
\hline 1 & 313,812 & 6 & 37,616 \\
2 & 111,220 & 7 & 30,890 \\
3 & 76,367 & 8 & 26,103 \\
4 & 60,366 & 9 & 20,937 \\
5 & 45,506 & 10 & 17,831 \\
\hline
\end{tabular}

The activity seems to be related to the willingness to provide personal information. Of those with missing country information, 54.9\% are inactive lenders. Of those reporting citizenship, only $18.6 \%$ are inactive lenders. The average numbers of loans are 2.56 for those not giving country information and 22.19 for those giving it. For the lenders covered by Table 4.3.2 who gave country information, the highest average number of loans was achieved by Norway, with 51.99, and the minimum by India, with 3.48 .

\section{Table 4.3.2}

Percentage of inactive lenders per year of affiliation

\begin{tabular}{llll}
\hline 2006 & $22.6 \%$ & 2011 & $36.6 \%$ \\
2007 & $28.7 \%$ & 2012 & $22.9 \%$ \\
2008 & $31.5 \%$ & 2013 & $29.0 \%$ \\
2009 & $37.3 \%$ & 2014 & $40.1 \%$ \\
2010 & $40.2 \%$ & 2015 & $92.0 \%$ \\
\hline
\end{tabular}

Table 4.3.3 shows the variation in lending activity across occupations. These results show that activity is stronger among those reporting their occupation and also that the commitment to lend is weaker in the educational than in the professional world.

\section{Table 4.3.3}

Lending activity by occupation

\begin{tabular}{lrrrrrr}
\hline & Student & Teaching & Retired & Manager & Engineer & Consultant \\
\hline Percentage not active & $34.7 \%$ & $26.0 \%$ & $17.3 \%$ & $29.2 \%$ & $25.6 \%$ & $27.7 \%$ \\
Average number of loans & 9.7 & 20.3 & 37.5 & 24.6 & 38.6 & 30.8 \\
\hline
\end{tabular}




\section{The Partners}

\subsection{Kiva Field Partners}

The Kiva field partners are the intermediaries between Kiva lenders and borrowers. Field partners can be microfinance institutions, social businesses, schools or nonprofit organizations, though they were initially restricted to microfinance institutions. A microfinance institution (MFI) is an organization that provides microfinance services - that is, financial services to low-income individuals or to those who do not have access to typical banking services. MFIs range from small nonprofit organizations to large commercial banks. Over the last few years, Kiva decided to form partnerships with new types of entities that do not fit the traditional microfinance institution mold, such as Strathmore University in Kenya and Barefoot Power in Tanzania. Some of these partners are companies, and others are schools, nonprofits and NGOs. They share a mission of reaching underserved populations with loan products tailored to borrower needs. Overall, partners typically target impoverished or marginalized areas to review loan applications and approve borrowers who demonstrate a need for a loan and a reasonable likelihood of repayment.

Partners are strong on social performance albeit different organizations have different social performance strengths. Since 2012, Kiva has been assigning badges to its field partners following an initial due diligence process. These badges, or Kiva social performance badges as they are called, are based on antipoverty focus, vulnerable group focus, client voice, family and community empowerment, entrepreneurial support, facilitation of savings and innovation. Badges help identify the social purpose of the partner, which may differ greatly from one microfinance institution to the next. The badges are assigned to Kiva field partners during an initial due diligence process and updated annually.

Partners review loan applications. Each borrower requesting a loan through Kiva has been reviewed and approved by a local field partner. Microfinance institutions vet the majority of borrowers on Kiva but there are cases where borrowers are vetted by field partners whose core business is not microfinance. As a result, the loan review process varies considerably from partner to partner and can depend on the partner's experience with a borrower, a borrower's capacity to repay or a borrower's expected future earnings.

Moreover, there is a variety of lending methodologies that Kiva's field partners use. While the most common approach is to lend directly to individual borrowers, another popular methodology is to lend to borrowers who belong to a borrowing group, such as a group of five women from the same village who know each other well. In some cases, when groups are bound by a group guarantee, loans to one member of the group are contingent on the other group members repaying on time. Because each member's livelihood depends on other members' repayment, a form of peer monitoring and support develops, which helps ensure high repayment rates. Group loans constitute $14 \%$ of all loans in the Kiva database.

Once a loan is approved by the partner, the partner then takes a picture of the borrower, provides a description of the loan use, and posts the profile information of that borrower to Kiva for funding. When an investor lends to a borrower, Kiva delivers the funds to the local field partner. The partner may choose to disburse the funds to the borrower or use the funds to backfill a loan that has already been disbursed to a borrower in order to expedite the availability of capital. The field partner will then make collections on that loan. Typically, loan officers will travel out to the borrower's location (such as a rural village) and collect a repayment on a regular basis (weekly, monthly or otherwise). Once funds are collected and approved for distribution, the field partner 
delivers funds to Kiva and Kiva's software system automatically distributes the repayments to each Kiva lender.

When Kiva first started, borrowers had to wait until their loans had been funded on the Kiva website before receiving the funds. Since then, the system has changed, so that loans are disbursed to borrowers before their stories are posted to Kiva's website. Up to March 2015, 90\% of the loans were disbursed in advance. Disbursing loans sooner has a positive impact on the borrowers, who no longer need to wait weeks to receive their funding and can thus take advantage of timesensitive business opportunities. With disbursal taking place before the posting of the loan, this implies that, if the loan is not fully funded - that is, if 30 days elapse without the loan attracting adequate funding - the field partner absorbs the expiration risk. Nonetheless, the default risk that accompanies fully funded loans remains with the lenders. This is disclosed on Kiva's site: each loan proposal states whether funds have been disbursed previously.

\subsection{Description of the Partner Population}

The status of a Kiva field partner indicates whether they are currently operating or not. In all, 269 out of the 381 partners in the Kiva database are labelled as active. The rest are closed, inactive or paused. The table below shows the distribution across regions.

\section{Table 5.2.1}

Partners' status by region

\begin{tabular}{lrrrr}
\hline Region & Active & Closed & Inactive & Paused \\
\hline Africa & 98 & 41 & 5 & 5 \\
Asia & 59 & 14 & 1 & 1 \\
Central America & 29 & 7 & - & 1 \\
Eastern Europe & 9 & 5 & - & - \\
Middle East & 15 & 4 & 2 & 1 \\
North America & 29 & 5 & 7 & 2 \\
Oceania & 4 & - & - & - \\
South America & 26 & 9 & 1 & 1 \\
Total & 269 & 85 & 16 & 11 \\
\hline
\end{tabular}

Most of the partners operate in a single country, and 11 of them operate in two countries. The rest have to be dealt with carefully, because they can be special cases. For instance, one partner operates in 13 countries, and another partner in 12 countries.

The average amount raised per loan by all partners is $\$ 796$. The average number of loans posted by partners operating in one or two countries is 2,327. For the multiple-country partners, the number is much lower, at 82.2. The tails of the partners' distribution show curious cases. Some examples are:

- The minimum number of postings is one (seven cases). The amount raised by one was zero, and the rest were high loans, in three cases loans of $\$ 50,000$.

- The maximum amount raised, achieved by Fundación Paraguaya, was $\$ 28,930,550$. Distributed among 14,665 loans, this gives \$1,962 per loan on average.

- Yunus is a special case. It posted four loans in four different countries, raising $\$ 173,900$, and got a $100 \%$ default rate. 


\subsection{Partner Risk and Interest Rate Policy}

In view of the repayment risk linked to the currency exchange rate, Kiva offers partners the option of protecting themselves against currency fluctuations. In cases where the US dollar appreciates by more than 10\% relative to a local currency, partners who opt for currency exchange loss protection will be responsible for covering only the first 10\% of the local currency's cost of appreciation while lenders will cover the remainder. This can help the field partner continue funding local borrowers even through difficult economic times. Among the population of partners, only 155 have a positive currency loss rate. Except in 10 cases, the rate is below 2\%. The maximum is Finance South Sudan Limited, with 4.48\%. On average, the loss rate is higher in Eastern Europe (0.74\%) and lower in Central America (0.02\%).

Furthermore, upon considering all risks to repayment, Kiva assigns a risk rating to each field partner that reflects the risk of institutional default. To calculate the rating, Kiva takes into consideration a number of different dimensions, including governance, management, staff, planning, audit, earnings, liquidity, capital, the management information system and internal controls, and transparency. A Kiva analyst generally visits potential partners to get an understanding of the quality of the organization in relation to these dimensions. Each dimension has a variety of subdimensions scored on a scale of zero to five, and the scores are based on documents provided by the organization and on the Kiva analyst's on-site visit. The analyst uses the risk rating calculated by the model to propose a star rating in half-point increments from one to five for the traditional field partner. This star rating reflects the risk of institutional default associated with each of Kiva's field partners, with five stars indicating the lowest risk of institutional default and one star indicating the highest risk of institutional default.

But Kiva does not always publish a formal risk rating for its field partners. If a field partner is not rated, that means that the partner fits into one of two categories. First, partners that go through a basic due diligence process or experimental partnership are not given a risk rating. Second, partners that go through a full due diligence process but are working in an industry for which Kiva does not have a risk model prepared would show up as unrated. An example of this might be a farm assistance program, as Kiva does not have a formal risk model prepared for that industry. Currently, 160 partners have no rating given. Among those that have been rated, 85 have a rating of zero. For the rest, the distribution of ratings has a reasonably symmetric distribution, with the peak at three stars. Interestingly, unrated partners show less activity but, on average, they raise more money per loan.

\section{Table 5.3.1}

Activity of rated and unrated partners

\begin{tabular}{lccc}
\hline & Loans posted & Amount raised & Raised/posted \\
\hline Unrated & 177.3 & $\$ 164,571$ & $\$ 3,942.80$ \\
Rated & $3,792.7$ & $\$ 3,002,160$ & $\$ 1,222.90$ \\
\hline
\end{tabular}

To mitigate operational risk, and although Kiva is recognized for its zero interest rate policy, field partners charge relatively high interest rates on loans. Interest is typically higher on loans from microfinance institutions in developing countries than interest rates on larger loans in developed countries because of the administrative costs of overseeing many tiny loans, and the increased risk. Kiva defends the interest rates of its partners by saying that they provide much better rates 
than local alternatives but must charge what they do because the costs of making a microloan in the developing world are higher compared to larger loans in the West.

In response to the high interest rates inherent in the original Kiva model, the organization launched a more direct peer-to-peer microlending platform, called Kiva Zip, in 2012. Kiva Zip transfers funds directly to borrowers without outsourcing disbursements and repayment collection to field partners. Instead, Kiva Zip partners with local institutions called trustees, who vet loan applicants, provide mentorship and may post profiles and updates on their behalf. Currently, Kiva Zip borrowers do not pay any interest or fees. Lenders are protected from currency risk but do not earn interest. Kiva Zip is considered an experimental platform and started out by offering loans in the United States and, until recently, in Kenya. But in September 2015, Kiva announced the closure of the Kenyan branch due to insurmountable operational difficulties related to both the disbursal of loans to and the repayment of loans by borrowers in remote areas. Despite the difficulties in Kenya, Kiva Zip's repayment rate was $89 \%$.

\section{The Loans}

\subsection{Kiva Loans}

The loan is the most important data object in the Kiva database since most other objects are in some way related to a loan. Every loan has a journal where Kiva or a partner can provide updates about this object. Each loan listing has information regarding the key details of the loan, such as the sector of the intended use of the loan, the borrower's gender and country of origin, and the status of the loan. Status is key in determining whether a loan has been successful or not. At a particular point in time, the loan status may be fundraising, funded, in repayment, paid, expired, defaulted or refunded. If the loan has expired, defaulted or been refunded, then it has not managed to complete the entire crowdfunding process successfully. The success rate may be affected by a number of factors, such as the gender and region of the borrower, bonus credit eligibility or the provision of an extensive description of the intended use of the loan.

The Kiva database also features attributes of the loans, and these can be one or more of the following: green, higher education, Islamic finance, youth, start-up, water and sanitation, vulnerable groups, fair trade, rural exclusion, mobile technology, underfunded areas, conflict zones, job creation, growing businesses, disaster recovery, innovative loans. In addition, loans can have one or more tags (\#) attached to them. Members of the Kiva "loan taggers" team assign the tags, and up to five tags are allowed per loan. Among the most frequent tags is "incomeproducing durable asset," which refers to loans for purchasing assets that will generate new revenue or reduce expenses for many years, such as ovens for bakeries and sewing machines.

The number of loans registered on Kiva surged dramatically in 2012 as a result of the credit limits program that was launched in 2011. The program aimed to give partners flexibility by relaxing monthly fundraising limits and promoting the number and diversity of loans on Kiva. Partners responded enthusiastically to the program by recruiting substantially more borrowers. As a result, the supply of loan requests drastically increased. Figure 6.1.1 depicts the annual posting of loan requests on the Kiva website since its inception. 


\section{Figure 6.1.1}

Loans per year

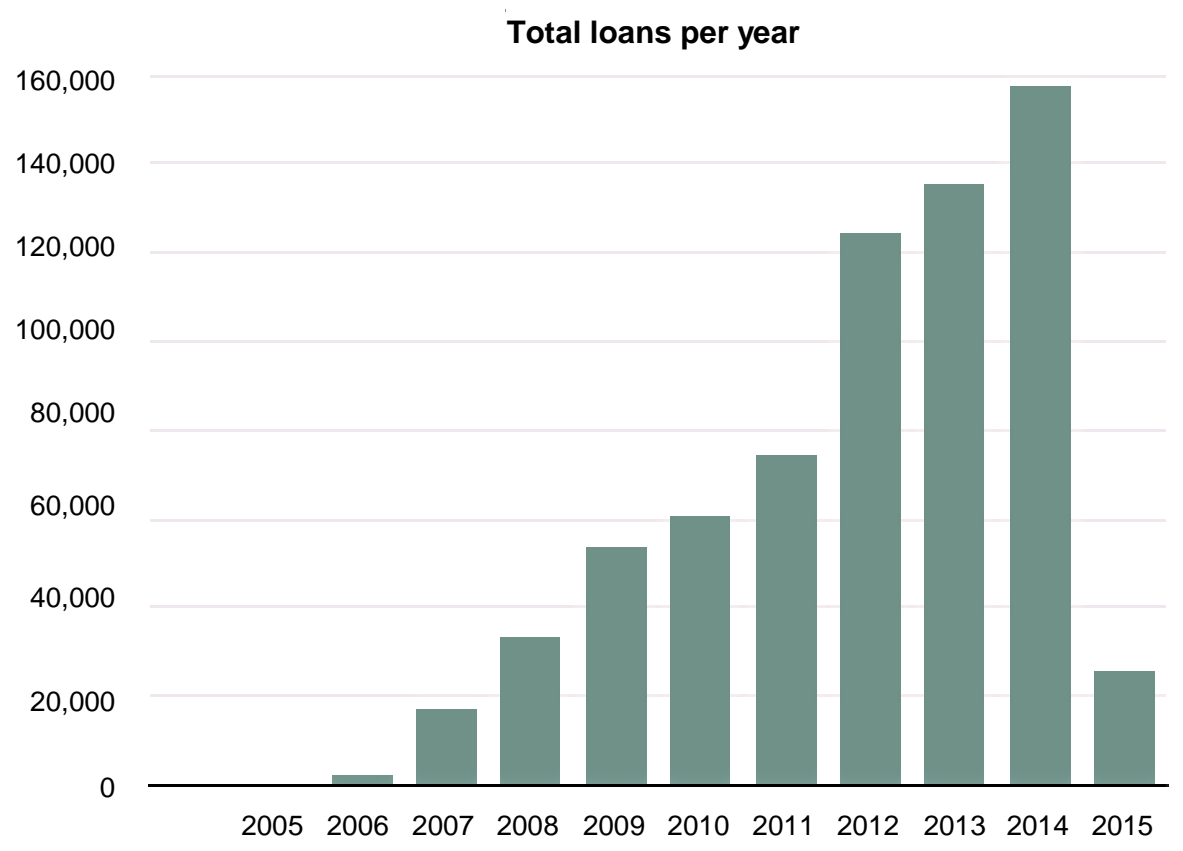

\subsection{Description of the Loan Population}

The processed data set contains 705,611 loan entries, categorized into 15 economic sectors, which are further subdivided into 149 activities. Loan requests come mostly from the food, agriculture and retail sectors. Activities related to the food sector include, for instance, fish selling, bakery, cereals and dairy. At the other extreme, loan requests from the entertainment, wholesale and health sectors are the least frequent throughout the period from 2005 to 2014 .

\section{Table 6.2.1}

Loan request distribution by sector

\begin{tabular}{lrrlrr}
\hline Sector & Frequency & \multicolumn{1}{c}{$\%$} & Sector & Frequency & $\%$ \\
\hline Agriculture & 161,766 & 22.93 & Housing & 29,763 & 4.22 \\
Arts & 13,184 & 1.87 & Manufacturing & 9,037 & 1.28 \\
Clothing & 44,228 & 6.27 & Personal use & 13,010 & 1.84 \\
Construction & 11,098 & 1.57 & Retail & 152,475 & 21.61 \\
Education & 17,943 & 2.54 & Services & 52,081 & 7.38 \\
Entertainment & 1,165 & 0.17 & Transportation & 21,940 & 3.11 \\
Food & 170,611 & 24.18 & Wholesale & 1,240 & 0.18 \\
Health & 6,071 & 0.86 & & & \\
\hline
\end{tabular}

The gender of the main borrower is also interesting to note. The great majority of borrowers are women, with the proportion rising to $74 \%$ (522,180 women compared to 183,431 men) throughout the entire period. Loan requests from women exceed those from men in all sectors apart from transportation, construction and entertainment. There are marginally more female entrepreneurs in the manufacturing sector as well. 


\section{Table 6.2.2}

Sector distribution by gender

\begin{tabular}{|c|c|c|c|c|c|}
\hline \multirow[t]{2}{*}{ Sector } & \multicolumn{2}{|c|}{ Female } & \multicolumn{2}{|c|}{ Male } & \multirow{2}{*}{$\begin{array}{c}\text { Total } \\
\text { Frequency }\end{array}$} \\
\hline & Frequency & $\%$ & Frequency & $\%$ & \\
\hline Agriculture & 103,605 & 64 & 58,161 & 36 & 161,766 \\
\hline Arts & 11,369 & 86 & 1,815 & 14 & 13,184 \\
\hline Clothing & 38,631 & 87 & 5,597 & 13 & 44,228 \\
\hline Construction & 4,946 & 45 & 6,152 & 55 & 11,098 \\
\hline Education & 10,553 & 59 & 7,390 & 41 & 17,943 \\
\hline Entertainment & 576 & 49 & 589 & 51 & 1,165 \\
\hline Food & 145,307 & 85 & 25,304 & 15 & 170,611 \\
\hline Health & 4,085 & 67 & 1,986 & 33 & 6,071 \\
\hline Housing & 18,509 & 62 & 11,254 & 38 & 29,763 \\
\hline Manufacturing & 4,719 & 52 & 4,318 & 48 & 9,037 \\
\hline Personal use & 8,243 & 63 & 4,767 & 37 & 13,010 \\
\hline Retail & 126,187 & 83 & 26,287 & 17 & 152,474 \\
\hline Services & 35,593 & 68 & 16,488 & 32 & 52,081 \\
\hline Transportation & 9,108 & 42 & 12,832 & 58 & 21,940 \\
\hline Wholesale & 749 & 60 & 491 & 40 & 1,240 \\
\hline Total & 522,180 & 74 & 183,431 & 26 & 705,611 \\
\hline
\end{tabular}

Furthermore, the loan requests come from 90 countries, which can be grouped into eight geographical regions - namely North America, Central America, South America, Africa, Eastern Europe, the Middle East, Asia and Oceania. More than one third of borrowers are in Asia, with Africa trailing in numbers. Oceania, North America and Eastern Europe record a very low number of loan requests.

\section{Table 6.2.3}

Loan request distribution by region

\begin{tabular}{lrr}
\hline Region & Frequency & $\%$ \\
\hline North America & 17,119 & 2.43 \\
Central America & 78,455 & 11.12 \\
South America & 113,769 & 16.12 \\
Africa & 196,057 & 27.78 \\
Eastern Europe & 17,690 & 2.51 \\
Middle East & 29,363 & 4.16 \\
Asia & 243,206 & 34.47 \\
Oceania & 9,952 & 1.41 \\
Total & $\mathbf{7 0 5 , 6 1 1}$ & $\mathbf{1 0 0 . 0 0}$ \\
\hline
\end{tabular}


In Africa, most loans are sought for the food, retail and agriculture sectors. Agricultural loans are the most popular in Asia, with food and retail scoring highly in that region as well. Agriculture is less popular in the Middle East and North America, where the records show a number closer to average. In the Middle East, services have the highest number of loan requests, followed by food and retail.

\section{Table 6.2.4}

Sector distribution by region

\begin{tabular}{lrrrrrrrr}
\hline & $\begin{array}{r}\text { North } \\
\text { America }\end{array}$ & $\begin{array}{r}\text { Central } \\
\text { America }\end{array}$ & $\begin{array}{c}\text { South } \\
\text { America }\end{array}$ & Africa & $\begin{array}{c}\text { Eastern } \\
\text { Europe }\end{array}$ & $\begin{array}{c}\text { Middle } \\
\text { East }\end{array}$ & Asia & Oceania \\
\hline Agriculture & 1,411 & 17,474 & 22,706 & 36,584 & 7,731 & 1,783 & 70,616 & 3,461 \\
Arts & 525 & 1,873 & 3,846 & 1,078 & 97 & 642 & 4,620 & 503 \\
Clothing & 1,835 & 5,658 & 7,077 & 17,523 & 2,206 & 2,141 & 7,381 & 407 \\
Construction & 601 & 1,890 & 2,234 & 2,893 & 212 & 1,030 & 2,203 & 35 \\
Education & 314 & 1,277 & 4,222 & 3,092 & 611 & 3,218 & 5,191 & 18 \\
Entertainment & 65 & 107 & 297 & 223 & 19 & 90 & 320 & 44 \\
Food & 3,488 & 17,009 & 26,052 & 63,455 & 1,610 & 4,693 & 51,419 & 2,885 \\
Health & 310 & 923 & 934 & 2,463 & 238 & 235 & 966 & 2 \\
Housing & 1,655 & 10,762 & 2,670 & 2,971 & 933 & 2,093 & 8,634 & 45 \\
Manufacturing & 212 & 962 & 1,559 & 1,449 & 193 & 683 & 3,972 & 7 \\
Personal use & 486 & 1,334 & 1,423 & 1,967 & 345 & 1,350 & 6,092 & 13 \\
Retail & 4,244 & 14,342 & 25,619 & 45,404 & 1,746 & 4,286 & 54,914 & 1,919 \\
Services & 1,679 & 3,918 & 10,935 & 13,074 & 948 & 6,073 & 15,009 & 445 \\
Transportation & 230 & 866 & 3,990 & 3,459 & 758 & 1,000 & 11,471 & 166 \\
Wholesale & 64 & 60 & 205 & 422 & 43 & 46 & 398 & 2 \\
\hline
\end{tabular}

While 74\% of borrowers are reported to be female, this proportion is exceeded in Oceania and Asia. However, in the Middle East, those requesting loans are balanced between men and women.

\section{Table 6.2.5}

Gender distribution by region

\begin{tabular}{lrrrrrrrr}
\hline & $\begin{array}{c}\text { North } \\
\text { America }\end{array}$ & $\begin{array}{c}\text { Central } \\
\text { America }\end{array}$ & $\begin{array}{c}\text { South } \\
\text { America }\end{array}$ & Africa & $\begin{array}{c}\text { Eastern } \\
\text { Europe }\end{array}$ & $\begin{array}{c}\text { Middle } \\
\text { East }\end{array}$ & Asia & Oceania \\
\hline Female & 11,945 & 50,599 & 82,582 & 138,666 & 10,356 & 14,452 & 203,665 & 9,915 \\
Male & 5,174 & 27,856 & 31,187 & 57,391 & 7,334 & 14,911 & 39,541 & 37 \\
\% Female & 70 & 65 & 73 & 71 & 59 & 49 & 84 & 99 \\
\hline
\end{tabular}

Group loans also exhibit some interesting tendencies. Group loans constitute 14\% of all loans in the data set, and this proportion has been relatively steady over the years, fluctuating only slightly between $12 \%$ and $17 \%$ since 2008. Most partners are accustomed to low rates of group loans, below 5\%, but some of them seem to specialize in them, showing rates of 100\% group loans. Figure 6.2.1 is a histogram of the percentage rates of group loans per partner. 


\section{Figure 6.2.1}

Rates of group loans

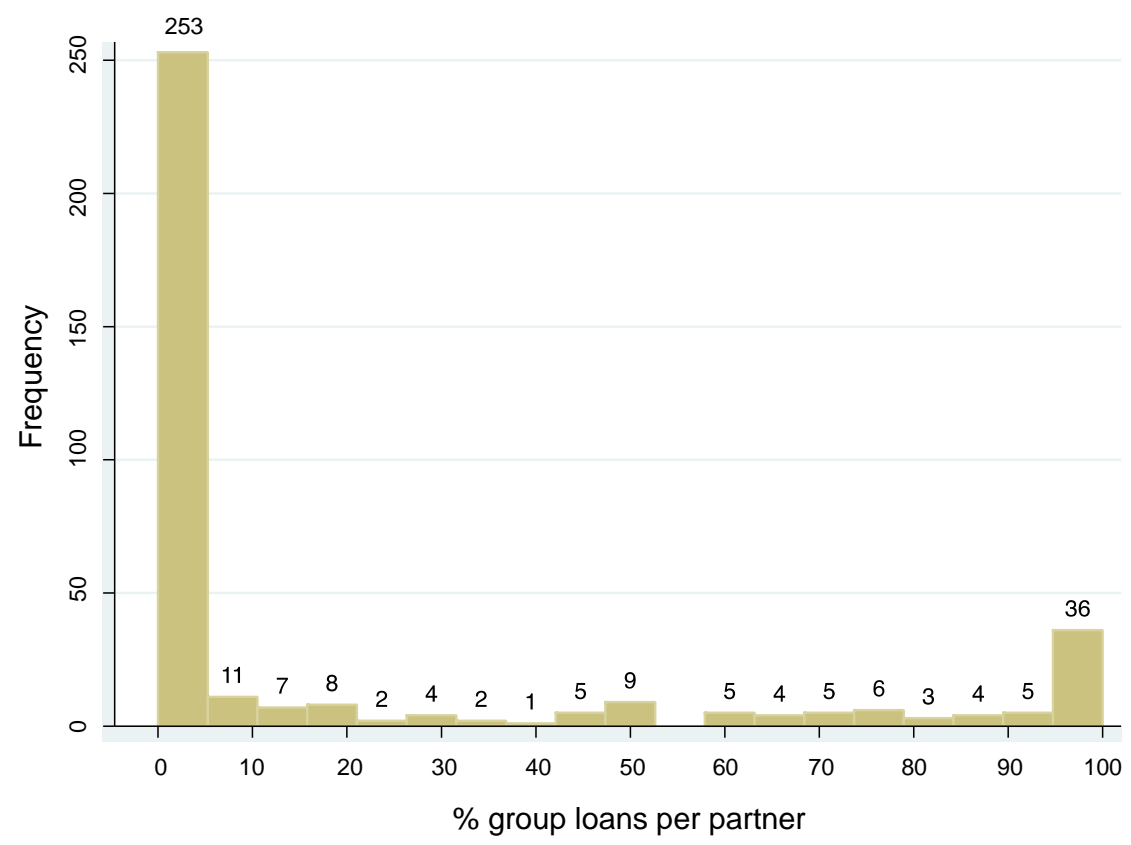

Group loans tend to list a woman more often than a man as the main borrower, as can be seen in Table 6.2.6. Specifically, $16 \%$ of loan requests from women are group claims while only $6 \%$ of male loans involve groups.

\section{Table 6.2.6}

Group distribution by gender

\begin{tabular}{lrrr}
\hline & Female & Male & Total \\
\hline Individual & 424,598 & 167,762 & 592,360 \\
Group & 82,768 & 10,677 & 93,445 \\
\% group & $16 \%$ & $6 \%$ & $14 \%$ \\
\hline
\end{tabular}

Group loans are most popular in North America. Considering that the average of group loans across all regions is 14\%, North America's rate of 28\% reveals a high inclination toward using the mechanism of peer pressure to mitigate risk. Africa follows with a 19\% proportion of group loans. At the other end, in Oceania and Eastern Europe the percentages are very small. Table 6.2.7 reports the popularity of group loans by region.

\section{Table 6.2.7}

Group distribution by region

\begin{tabular}{lrrrrrrrr}
\hline & $\begin{array}{r}\text { North } \\
\text { America }\end{array}$ & $\begin{array}{r}\text { Central } \\
\text { America }\end{array}$ & $\begin{array}{r}\text { South } \\
\text { America }\end{array}$ & Africa & $\begin{array}{r}\text { Eastern } \\
\text { Europe }\end{array}$ & $\begin{array}{r}\text { Middle } \\
\text { East }\end{array}$ & Asia & Oceania \\
\hline Individual & 11,719 & 69,531 & 93,908 & 153,335 & 17,357 & 25,151 & 211,742 & 9,617 \\
Group & 4,660 & 7,002 & 16,039 & 36,991 & 2 & 3,556 & 25,103 & 92 \\
\% group & $28 \%$ & $9 \%$ & $15 \%$ & $19 \%$ & $0 \%$ & $12 \%$ & $11 \%$ & $1 \%$ \\
\hline
\end{tabular}


In addition, Table 6.2.8 reports the popularity of group loans by sector. There are numerous sectors where a high proportion of loan requests are for group loans. These include agriculture, the arts, clothing, health and personal use. Unsurprisingly, housing, education and transportation report low numbers of group loans in relation to the sector total, since these sectors usually involve requests for loans with purposes such as repairing one's house, pursuing a higher level of education and obtaining a form of personal transport.

\section{Table 6.2.8}

Group distribution by sector

\begin{tabular}{lrrr}
\hline & Individual & Group & $\%$ group \\
\hline Agriculture & 134,947 & 22,950 & $15 \%$ \\
Arts & 10,175 & 2,571 & $20 \%$ \\
Clothing & 34,808 & 7,990 & $19 \%$ \\
Construction & 9,650 & 1,026 & $10 \%$ \\
Education & 17,148 & 673 & $4 \%$ \\
Entertainment & 1,055 & 69 & $6 \%$ \\
Food & 140,501 & 24,930 & $15 \%$ \\
Health & 4,745 & 1,148 & $19 \%$ \\
Housing & 27,789 & 1,398 & $5 \%$ \\
Manufacturing & 7,896 & 854 & $10 \%$ \\
Personal use & 10,175 & 2,661 & $21 \%$ \\
Retail & 128,041 & 19,726 & $13 \%$ \\
Services & 44,058 & 6,410 & $13 \%$ \\
Transportation & 20,320 & 902 & $4 \%$ \\
Wholesale & 1,052 & 137 & $12 \%$ \\
\hline
\end{tabular}

To conclude the description of the loan data, we note that the amount of the loan varies greatly, from $\$ 25$ to $\$ 100,000$, with a mean of $\$ 854$. In addition, some loans are denoted as paid but the paid amount is less than the funded amount, which means that the borrower repaid only part of the loan and this was considered satisfactory. This may appear strange but it occurs in 1,974 cases and can be explained by currency exchange rate fluctuations.

\subsection{Loan Status: Success or Failure}

Out of the 705,611 loans in the processed data set, the vast majority of loans, 94.37\%, have been successful in the process of raising funds and repaying the amount. However, 14,170 loans (2.01\%) have ended with a default on the payments and 21,814 loans (3.09\%) have expired after the full amount requested was not received within 30 days of the request being posted. Furthermore, 3,725 loans (0.53\%) have been refunded, which may have occurred for a number of reasons including the discovery of errors and misalignment with Kiva policy. 


\section{Table 6.3.1}

Loan status

\begin{tabular}{lrr}
\hline Status & Frequency & $\%$ \\
\hline Defaulted & 14,170 & 2.01 \\
Expired & 21,814 & 3.09 \\
Funded & 654 & 0.09 \\
Fundraising & 3,582 & 0.51 \\
In repayment & 141,453 & 20.05 \\
Paid & 520,213 & 73.73 \\
Refunded & 3,725 & 0.53 \\
Total & 705,611 & 100 \\
\hline
\end{tabular}

The loan is deemed unsuccessful if it has expired, defaulted or been refunded. It is interesting to note that, whereas expiration occurs $60 \%$ of the time for loans requested by men, default is more closely associated with women, with $69 \%$ of defaults associated with female borrowers. This means that women are more likely to receive funding than men but the lender is facing a greater risk.

\section{Table 6.3.2}

Status distribution by gender

\begin{tabular}{|c|c|c|c|c|c|}
\hline \multirow[t]{2}{*}{ Status } & \multicolumn{2}{|c|}{ Female } & \multicolumn{2}{|c|}{ Male } & \multirow{2}{*}{$\begin{array}{c}\text { Total } \\
\text { Frequency }\end{array}$} \\
\hline & Frequency & $\%$ & Frequency & $\%$ & \\
\hline Defaulted & 9,719 & 69 & 4,451 & 31 & 14,172 \\
\hline Expired & 8,772 & 40 & 13,042 & 60 & 21,814 \\
\hline Funded & 446 & 68 & 208 & 32 & 654 \\
\hline Fundraising & 2,129 & 59 & 1,453 & 41 & 3,582 \\
\hline In repayment & 105,200 & 74 & 36,253 & 26 & 141,456 \\
\hline Paid & 393,481 & 76 & 126,732 & 24 & 520,221 \\
\hline Refunded & 2,433 & 65 & 1,292 & 35 & 3,725 \\
\hline Total & 522,180 & 74 & 183,431 & 26 & 705,611 \\
\hline
\end{tabular}

Delinquency occurs because the borrower or the field partner has fallen behind with repayments. Delinquency is a temporary situation and thus less useful for historical data. Only loans that have defaulted or are in repayment status may be delinquent. At the time the data snapshot was taken (March 9, 2015), 99\% of all defaulted loans are marked as delinquent, and 15\% of loans in repayment are delinquent. Interestingly, not all loan listings are accompanied by an elaborate description and our data seem to show a strong correlation between the lack of description and the likelihood of a default. However, we cannot exclude the possibility of a technical issue in the description field and hence chose not to elaborate on this finding. 
Table 6.3.3 shows the distribution of bonus credit eligibility by status. Overall, 61\% of the loans have a bonus credit eligibility of one. The presence of eligibility decreases the likelihoods of a default and refund but contributes negatively to expiration by increasing the likelihood the loan will never receive the funding it seeks.

\section{Table 6.3.3}

Status distribution by bonus credit eligibility

\begin{tabular}{|c|c|c|c|c|}
\hline \multirow[t]{2}{*}{ Status } & \multicolumn{2}{|c|}{0 (not eligible) } & \multicolumn{2}{|l|}{1 (eligible) } \\
\hline & Frequency & $\%$ & Frequency & $\%$ \\
\hline Defaulted & 10,319 & 73 & 3,851 & 27 \\
\hline Expired & 8,640 & 40 & 13,174 & 60 \\
\hline Funded & 243 & 37 & 411 & 63 \\
\hline Fundraising & 1,123 & 31 & 2,459 & 69 \\
\hline In repayment & 56,052 & 40 & 85,401 & 60 \\
\hline Paid & 199,167 & 38 & 321,046 & 62 \\
\hline Refunded & 2,504 & 67 & 1,221 & 33 \\
\hline Total & 278,048 & 39 & 427,563 & 61 \\
\hline
\end{tabular}

Moreover, the frequency of expiration is rather high when loans are associated with retail, agriculture, food or housing. The first three of these categories are also related to a high incidence of defaulting. The housing sector, however, carries a very low likelihood of a default. Table 6.3.4 reports the distribution of loan status across the various sectors, in percentage terms.

\section{Table 6.3.4}

Status distribution by sector, $\%$

\begin{tabular}{lrrrrrrr}
\hline & Defaulted & Expired & Funded & Fundraising & In repayment & Paid & Refunded \\
\hline Agriculture & 21.1 & 20.0 & 27.8 & 34.0 & 27.9 & 21.7 & 21.0 \\
Arts & 1.8 & 0.0 & 4.3 & 0.2 & 1.5 & 2.1 & 1.4 \\
Clothing & 7.8 & 7.2 & 3.8 & 4.2 & 4.7 & 6.6 & 7.2 \\
Construction & 1.6 & 0.8 & 0.9 & 1.6 & 1.2 & 1.7 & 2.3 \\
Education & 0.7 & 0.6 & 3.7 & 1.5 & 6.3 & 1.7 & 1.3 \\
Entertainment & 0.3 & 0.1 & 0.0 & 0.1 & 0.1 & 0.2 & 0.1 \\
Food & 24.5 & 15.8 & 15.3 & 18.2 & 19.6 & 25.8 & 25.1 \\
Health & 1.3 & 0.0 & 1.2 & 0.3 & 1.3 & 0.8 & 1.3 \\
Housing & 1.7 & 14.7 & 6.1 & 7.7 & 7.0 & 3.0 & 4.7 \\
Manufacturing & 1.1 & 0.0 & 1.1 & 0.3 & 1.2 & 1.4 & 1.1 \\
Personal use & 0.8 & 3.5 & 4.9 & 2.8 & 3.8 & 1.3 & 3.1 \\
Retail & 25.3 & 25.9 & 18.2 & 17.3 & 16.3 & 22.8 & 20.0 \\
Services & 8.2 & 6.4 & 8.7 & 7.3 & 6.7 & 7.6 & 8.6 \\
Transportation & 3.5 & 4.8 & 4.0 & 4.5 & 2.3 & 3.3 & 2.3 \\
\hline Wholesale & 0.2 & 0.1 & 0.0 & 0.1 & 0.1 & 0.2 & 0.4 \\
\hline
\end{tabular}


Table 6.3.5 reports the distribution of loan status across regions, in percentage terms. Exploring the data by region, we find that the highest likelihood of a default is for loan requests originating in North America. Expiration rates are high in Eastern Europe, the Middle East and Central America.

\section{Table 6.3.5}

Status distribution by region, \%

\begin{tabular}{lcccccccc}
\hline & $\begin{array}{c}\text { North } \\
\text { America }\end{array}$ & $\begin{array}{c}\text { Central } \\
\text { America }\end{array}$ & $\begin{array}{c}\text { South } \\
\text { America }\end{array}$ & Africa & $\begin{array}{c}\text { Eastern } \\
\text { Europe }\end{array}$ & $\begin{array}{c}\text { Middle } \\
\text { East }\end{array}$ & Asia & Oceania \\
\hline Defaulted & 4.6 & 1.5 & 1.7 & 3.7 & 0.7 & 1.8 & 1.0 & 0.3 \\
Expired & 2.5 & 6.6 & 3.6 & 1.7 & 8.4 & 7.8 & 2.0 & 1.4 \\
Funded & 0.1 & 0.1 & 0.1 & 0.1 & 0.1 & 0.0 & 0.1 & 0.0 \\
Fundraising & 0.2 & 0.9 & 0.4 & 0.4 & 1.2 & 0.6 & 0.5 & 0.3 \\
In repayment & 15.7 & 22.8 & 12.8 & 19.4 & 29.7 & 27.1 & 21.6 & 25.2 \\
Paid & 75.9 & 67.4 & 81.0 & 73.8 & 59.5 & 62.4 & 74.6 & 72.5 \\
\hline Refunded & 1.0 & 0.7 & 0.4 & 0.9 & 0.4 & 0.4 & 0.2 & 0.4 \\
\hline
\end{tabular}

Finally, the listing of the loan request as an individual or group loan request seems to have some effect on the success of the loan. The idea behind group loans is to provide a way to secure loans without having to rely on collateral as would happen with bank loans. Hence, it is not surprising to see that loan requests that originate from groups have a lower expiration rate than average, at $9 \%$. However, among defaulted loans, $17 \%$ are group loans, which is higher than average. Table 6.3.6 reports these results, which seem to indicate that, although group loans are considered less risky and thus attract funding more easily than individual loans, in reality group loans are more likely to end in a default than individual loans, contrary to popular wisdom. In fact, out of all group loans, only $2.1 \%$ expire whereas $3.4 \%$ of individual loans expire. In terms of defaulting, group loans expire more frequently than individual loans, at the rate of $2.4 \%$ compared to $1.9 \%$. Finally, we note that the refund rate is the same across the two groups.

\section{Table 6.3.6}

Group distribution by status

\begin{tabular}{lrrrrrrr}
\hline & Defaulted & Expired & Funded & Fundraising & In repayment & Paid & Refunded \\
\hline Individual & 11,328 & 19,864 & 542 & 3,089 & 122,614 & 431,828 & 3,095 \\
Group & 2,279 & 1,937 & 112 & 493 & 18,838 & 69,365 & 421 \\
\% group & $17 \%$ & $9 \%$ & $17 \%$ & $14 \%$ & $13 \%$ & $14 \%$ & $12 \%$ \\
\hline
\end{tabular}

\section{The Drivers of Success and Failure in Fundraising}

\subsection{Expiration}

With Kiva, if a loan is not fully funded within 30 days of being listed on the website, it expires. This means that the loan profile remains on the site but shows up as expired, all lenders who have chipped in to fund the loan get a refund, and the field partner administering the loan does not receive any of the funds. In our analysis, out of the 705,611 loans, 21,814 expired after not being 
able to attract the requested funding within a period of 30 days. This corresponds to a 3.09\% expiration rate.

Expirations occur when there are more loans on the website than there are lenders to fund them, and they relate to changes in the demand for and supply of loans over time. The historical rate of expiration since Kiva's launch in 2005 has varied greatly. Prior to 2012, fewer than 100 loans expired every year. In 2009, when expired loans first appeared, these amounted to only 48. In 2010, 58 more loans expired and, in 2011, 36 more. Expired loans picked up pace in March 2012 and jumped from 142 at the end of 2011 to 6,982 one year later. The remarkable increase continued in 2013 and 2014, reaching the volume of 20,364 by the end of 2014. During the first two months of 2015, 1,450 more loans expired. Table 7.1.1 also shows the sudden and major increase in the yearly expiration rate in 2012 .

Table 7.1.1

Total loans vs. expired loans

\begin{tabular}{|c|c|c|c|c|c|c|c|}
\hline \multirow[t]{2}{*}{ Year } & \multicolumn{3}{|c|}{ Total loans } & \multicolumn{4}{|c|}{ Expired loans } \\
\hline & Frequency & $\begin{array}{c}\text { Cumulative } \\
\text { frequency }\end{array}$ & $\begin{array}{c}\text { Rate of } \\
\text { change, \% }\end{array}$ & Frequency & $\begin{array}{c}\text { Cumulative } \\
\text { frequency }\end{array}$ & $\begin{array}{c}\text { Rate of } \\
\text { change, \% }\end{array}$ & $\begin{array}{c}\text { Rate of } \\
\text { expiration, \% }\end{array}$ \\
\hline 2005 & 38 & 38 & - & - & - & - & - \\
\hline 2006 & 2,030 & 2,068 & 5,342 & - & - & - & - \\
\hline 2007 & 16,964 & 19,032 & 820 & - & - & - & - \\
\hline 2008 & 33,214 & 52,246 & 175 & - & - & - & - \\
\hline 2009 & 53,876 & 106,122 & 103 & 48 & 48 & - & 0.09 \\
\hline 2010 & 60,999 & 167,121 & 57 & 58 & 106 & 121 & 0.10 \\
\hline 2011 & 74,051 & 241,179 & 44 & 36 & 142 & 34 & 0.05 \\
\hline 2012 & 131,320 & 372,492 & 54 & 6,840 & 6,982 & 4,817 & 5.49 \\
\hline 2013 & 139,524 & 512,016 & 37 & 4,035 & 11,017 & 58 & 2.98 \\
\hline 2014 & 166,655 & 678,671 & 33 & 9,347 & 20,364 & 85 & 5.94 \\
\hline 2015 & 26,940 & 705,611 & 4 & 1,450 & 21,814 & 7 & 5.69 \\
\hline
\end{tabular}

The record levels of expiration since 2012 can be attributed to the high volume of loan requests being posted on Kiva. The credit limits program, launched in 2011, has upset the balance between the supply of loan requests and the demand from lenders. The enthusiastic response of partners to the relaxation of fundraising limits led to the registration of more loan requests, thereby drastically increasing their supply. The significant increase in the volume of loan requests is important in that it has affected all loan requests, not just the loan requests posted by partners in the credit limits program. Prior to the increase, expirations were constrained to partners who posted loan requests that were less attractive to lenders, such as male taxi drivers in the Middle East with blurry profile pictures. Traditionally, most expirations occur when lenders do not feel a connection with a borrower through their photo or story or if they are skeptical about the difference the loan will make in the borrower's life. But, since 2012, expirations are affecting Kiva's entire portfolio, including loans that have traditionally been funded quickly, such as agricultural loans for women in Africa. The increased supply is creating competition between loan requests. 
It is also interesting to note the association between the expiration rate and the month in which the loan is posted. Since crowdfunding is an online activity, it requires time and Internet access. Therefore, months during which people tend to be on vacation, such as June and December, and months that are deemed busier, such as the start of the new school year in September, experience higher expiration rates on average, as per Figure 7.1.3.

\section{Figure 7.1.3}

Expirations per month

6

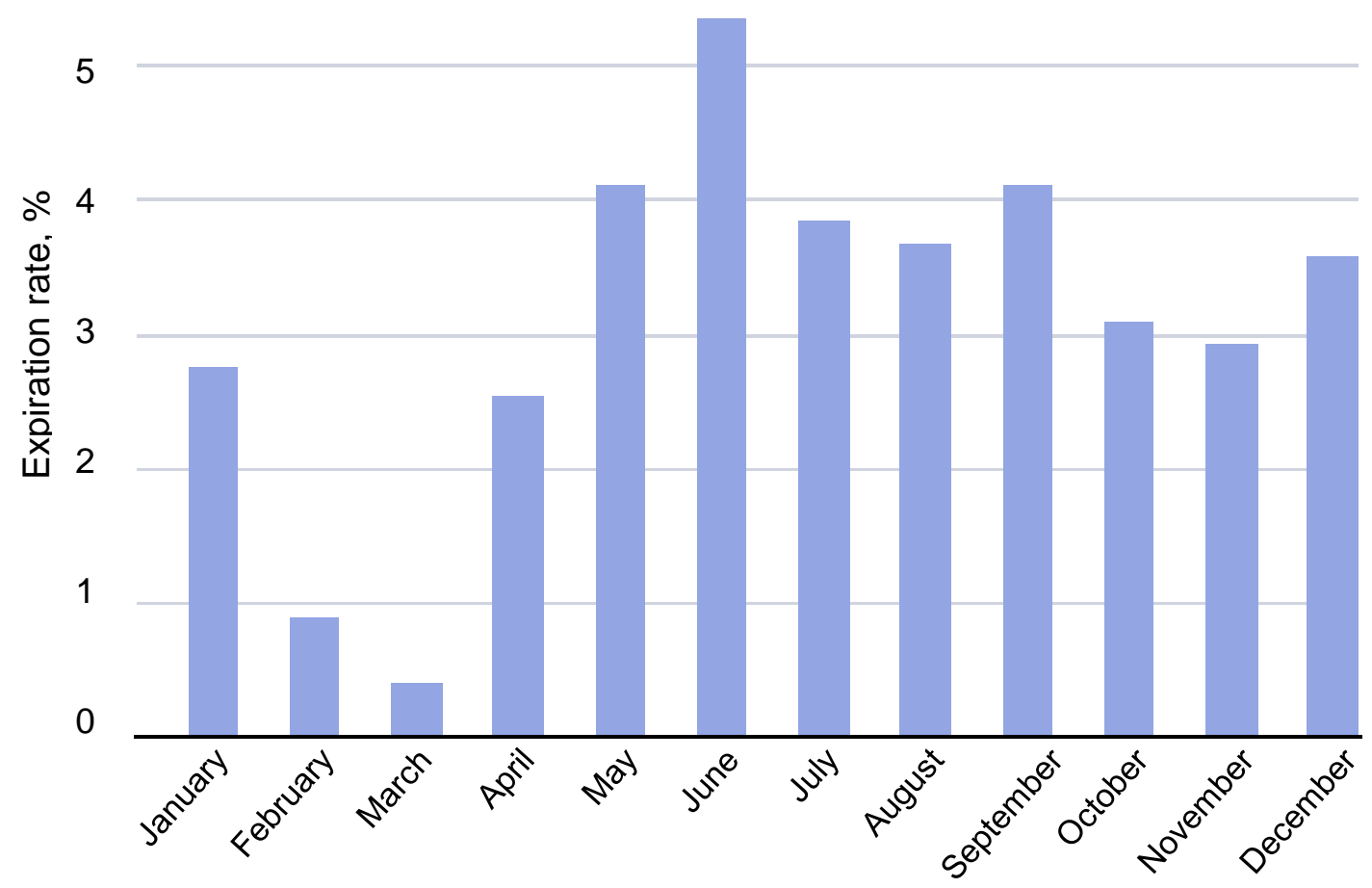

Our analysis in the previous section allows us to make some interesting observations on the factors that pertain to the borrower, loan, lender and partner characteristics and that seem to affect expiration. First, the borrower's gender seems to have an effect on expiration. Whereas $74 \%$ of the borrowers are women, among female borrowers the likelihood of expiration is much lower at $1.7 \%$, compared to men where the expiration rate rises to $7.1 \%$.

The effect of the region is depicted in Table 7.1.2. Most loan requests originate in Asia $(290,000)$ and Africa $(240,000)$. Nonetheless, these loans are the least likely to expire, with an expiration rate of 1.7\% in Asia and 1.4\% in Africa - well below the global average expiration rate of 2.6\%. However, loans from Eastern Europe have the highest incidence of expiration (8\%), followed by the Middle East (7\%) and Central America (6\%). With respect to country, loan requests from the Philippines are the most frequent $(125,000)$, followed by Kenya $(64,000)$, Peru $(55,000)$, Cambodia $(37,000)$, Nicaragua $(28,000)$ and El Salvador $(32,000)$. But countries associated with a high expiration rate are El Salvador (15\%), Colombia (8.3\%), Tajikistan (7.2\%), Nicaragua (6.3\%), Uganda (5.6\%), Kenya (5.3\%), Jordan (4.6\%), the Philippines (4.4\%), Armenia (4.2\%), Peru (4\%) and Bolivia (3.2\%). 
Table 7.1.2

Expiration by region

\begin{tabular}{lcc}
\hline Region & All loans & Expired loans \\
\hline North America & $2 \%$ & $2.5 \%$ \\
Central America & $11 \%$ & $6.6 \%$ \\
South America & $16 \%$ & $3.6 \%$ \\
Africa & $28 \%$ & $1.8 \%$ \\
Eastern Europe & $2 \%$ & $8.7 \%$ \\
Middle East & $4 \%$ & $7.8 \%$ \\
Asia & $34 \%$ & $2.0 \%$ \\
Oceania & $1 \%$ & $1.4 \%$ \\
\hline
\end{tabular}

Moreover, the sector in which the loan is to be used plays a role. Loan requests with the lowest expiration rates involve the arts, health and manufacturing. At the other end, the sectors that are associated with an above-average expiration rate are housing (10.8\%), personal use (5.8\%), transportation (4.7\%), retail (3.7\%) and clothing (3.6\%). In addition, a comparison shows that the loan amount requested in the case of expired loans is greater on average than the amount requested for all other, unexpired loans (\$1,556 vs. \$831).

Other loan characteristics also play a role in whether it is successful. With respect to the repayment interval and term, expired loans tend to have irregular repayment intervals $(72 \%$ of them), whereas loans that did not expire mostly have monthly repayment intervals (69\%). Only $17 \%$ of expired loans were designed with monthly repayments. The average repayment term for expired loans is higher (18 months vs. 13 months). And group loans enjoy lower expiration rates than individual loans, at $2.1 \%$ compared to $3.4 \%$. However, bonus credit eligibility does not appear to have an effect since all loans, irrespective of bonus credit eligibility, have a very similar likelihood of expiration.

Finally, the field partners shown in Table 7.1.3 have the highest expiration rates in the data set. The diversity among them, however, prevents us from commenting on the partner characteristics that are associated with more expirations. In first place, Thrive Networks in Vietnam is a nonprofit organization that directs Kiva lenders' funds to help borrowers obtain clean water and quality sanitation equipment. Next, the Pacific Asian Consortium in Employment operates in a completely different field as it is based in Los Angeles, California, and focuses on supporting new business opportunities and creating jobs. Moving down the list, the Jordan Micro Credit Company (known as Tamweelcom) is a nonprofit microfinance institution founded to support small business projects and provide financial services for the low-income community and women who are not eligible for commercial financing. 
Table 7.1.3

Expiration by partner

\begin{tabular}{lllc}
\hline Partner ID & Partner's name & Region & Expiration rate \\
\hline 331 & Thrive Networks, Vietnam & Asia & $51 \%$ \\
268 & Pacific Asian Consortium in Employment & North America & $29 \%$ \\
174 & Tamweelcom & Middle East & $27 \%$ \\
265 & Latino Economic Development Center & North America & $27 \%$ \\
173 & LiftFund & North America & $26 \%$ \\
295 & PAC & Central America & $22 \%$ \\
333 & CONFRAS & Central America & $21 \%$ \\
219 & PT Rekan Usaha Mikro Anda (Ruma) & Asia & $20 \%$ \\
\hline
\end{tabular}

\subsection{Defaults}

With a 98\% repayment rate to date, the vast majority of Kiva loans are paid back in full. Nonetheless, there is a small fraction of loan recipients who are unable to repay their loans. Out of the 705,611 loans, 14,170 ended up with the borrowers defaulting on the repayment, after at least six months of failing to keep up with the repayment schedule. This corresponds to a $2.01 \%$ default rate.

A default occurs when a borrower or a field partner fails to make payments on a loan, to the field partner or to Kiva respectively. As already indicated, risks to repayment can be associated with the borrower, the partner or the exchange rate. In the case of the borrower risk, Kiva field partners screen loan applications before accepting them, by looking at factors such as the past loan history, village or group reputation and loan purpose. Despite these precautions, a variety of factors can result in borrowers defaulting. These include business issues such as crop failure, health issues such as malaria and other issues such as theft, overindebtedness and civil disturbances. With respect to the field partner, a default may be the result of bankruptcy, fraud or operational difficulties. When repayment difficulties crop up, the loan first becomes delinquent but continues to have the in repayment status. If a loan remains delinquent for six months after the end of the loan payment schedule, then the loan becomes defaulted. Defaulted loans constitute a financial loss to the lenders who financed that loan - that is, the lenders never get their money back. Kiva keeps track of the default rate per partner, and calculates it as the percentage of ended loans (no longer being paid back) that have failed to be repaid (measured in dollar volume, not units).

The historical rate of defaulting since Kiva's launch in 2005 has varied greatly from 13\% in the beginning to $0.1 \%$ in 2014 . With the exception of a spike in defaults in 2012 , from $2 \%$ the previous year to $4 \%$, the default rate has been steadily decreasing over the period. In 2014, only 134 loans defaulted out of a total of 157,308 loans registered. We note, however, that the default rates registered in 2013, 2014 and 2015 may increase in the future, since the date is that of the loan request being posted online and not that of repayment. Table 7.2.1 shows the yearly default rates, and Figure 7.2.1 graphically juxtaposes the number of defaulted loans and the total number of loans on a yearly basis. 
Table 7.2.1

Total loans vs. defaulted loans

\begin{tabular}{lrrc}
\hline Year & Total loans & Defaulted loans & Rate of default \\
\hline 2005 & 38 & 5 & $13 \%$ \\
2006 & 2,030 & 192 & $9 \%$ \\
2007 & 16,964 & 1,409 & $8 \%$ \\
2008 & 33,214 & 730 & $2 \%$ \\
2009 & 53,828 & 1,099 & $2 \%$ \\
2010 & 60,941 & 1,909 & $3 \%$ \\
2011 & 74,015 & 1,525 & $2 \%$ \\
2012 & 124,480 & 4,818 & $4 \%$ \\
2013 & 135,489 & 2,349 & $2 \%$ \\
2014 & 157,308 & 134 & $0.1 \%$ \\
2015 & 25,490 & 0 & $0 \%$ \\
\hline
\end{tabular}

Figure 7.2.1

Defaulted loans

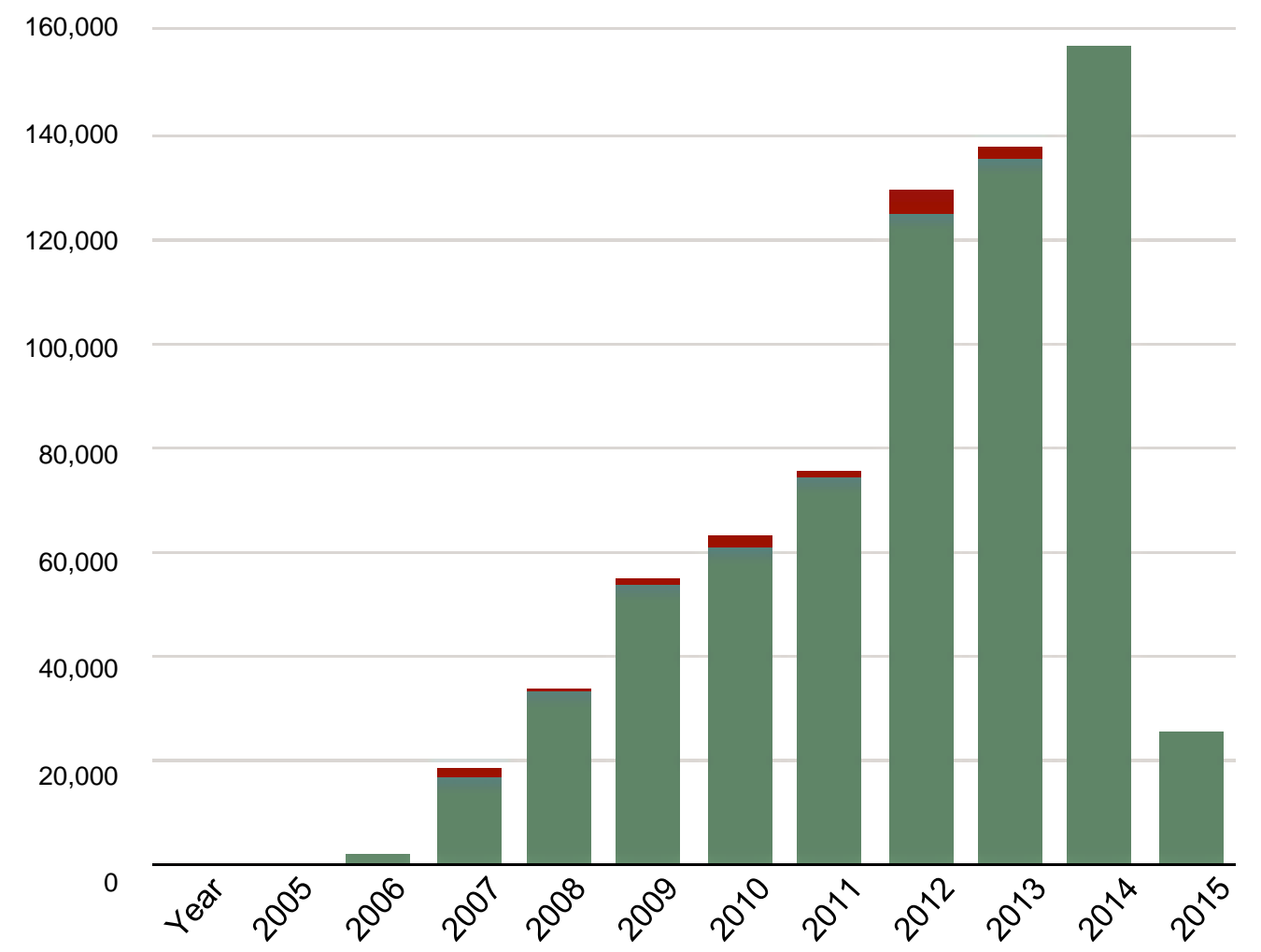

Our previous analysis shows how gender affects the probability of defaulting. Among female borrowers, the likelihood of defaulting is $1.9 \%$ whereas, among male borrowers, this rises to $2.4 \%$. Moreover, loans originating in North America and Africa have the highest likelihood of a default. 


\section{Table 7.2.1}

Default rate by region

\begin{tabular}{lcc}
\hline Region & All loans & Defaulted loans \\
\hline North America & $2 \%$ & $4.6 \%$ \\
Central America & $11 \%$ & $1.5 \%$ \\
South America & $16 \%$ & $1.7 \%$ \\
Africa & $28 \%$ & $3.7 \%$ \\
Eastern Europe & $2 \%$ & $0.7 \%$ \\
Middle East & $4 \%$ & $1.8 \%$ \\
Asia & $34 \%$ & $1.0 \%$ \\
Oceania & $1 \%$ & $0.3 \%$ \\
\hline
\end{tabular}

With regard to the specific characteristics of the loan, the sector seems to matter. Loans with the lowest default rates involve the education, housing and personal use sectors. At the other extreme, the sectors that are associated with high default rates are entertainment $(4.2 \%)$, health $(2.9 \%)$ and clothing (2.5\%). Loans for transportation, retail, services and wholesale default at a rate of about $2.3 \%$.

In addition, and contrary to expectations, group loans end in a default more often than individual loans, at a rate of $2.4 \%$ compared to $1.5 \%$. In line with expectations, loans with zero bonus credit eligibility tend to default more frequently, at a rate of 3.7\%, unlike loans with high bonus credit eligibility, which default at the low rate of $0.9 \%$. A comparison shows that the loan amount requested in the case of defaulted loans is less on average than the amount requested for all loans with no default ( $\$ 790$ vs. $\$ 856$ ) and that the amount requested was up to $\$ 25,000$ in the case of defaulted loans compared to up to $\$ 100,000$ for all other loans. In this respect, the loan amount does not seem to be an indicator of the likelihood of defaulting. Furthermore, as far as the repayment interval and term are concerned, there does not seem to be much influence. Both those loans that ended in a default and those loans that did not were mostly designed with monthly repayments and the average repayment term was 13 months in both cases.

Some field partners have exceptionally high default rates, which led Kiva to cease or suspend collaboration with them. For instance, the Shurush Initiative was a nonprofit organization dedicated to improving the grave economic situation in the West Bank and Gaza Strip through transparent microfinance and proactive employment. But due to turmoil in the region and trouble collecting repayments, Shurush stopped its lending operations in 2006, with a default rate of $57 \%$. Even higher is the default rate of Motorbank Kenya at 67\%. This microfinance institution focuses on poor clients in remote rural areas that are difficult to access. The partnership with Motorbank Kenya was at an experimental stage when Kiva decided to suspend their collaboration because of the high default rate. On the other side of the coin, some field partners have managed 0\% default rates. An example is Grameen America, a nonprofit microfinance organization that provides loans, education and other financial services to poor people in the United States. 


\subsection{Refunds}

On rare occasions, a loan is refunded, which means that Kiva returns the funded portion of the loan to lenders after the loan has been partially or fully funded or even during repayment. There are many reasons why a loan can be refunded but usually it is because of an error with the posting or the loan itself has been found to violate Kiva's loan policy. Only 3,725 loans have been refunded, which corresponds to a very low rate of $0.5 \%$.

Most refunds were given between 2009 and 2011 but, in relative terms, the biggest proportion was in 2006 when the refund rate peaked at 10\%. In all other years, the rate remained very low and it has been below 1\% since 2011. In 2014, only 310 loans were refunded out of a total of 157,308 loans registered. Table 7.3.1 shows the yearly refund rates.

\section{Table 7.3.1}

Total loans vs. refunded loans

\begin{tabular}{lccc}
\hline Year & Total loans & Refunded loans & Refund Rate \\
\hline 2005 & 38 & 0 & $0 \%$ \\
2006 & 2,030 & 211 & $10 \%$ \\
2007 & 16,964 & 169 & $1 \%$ \\
2008 & 33,214 & 230 & $1 \%$ \\
2009 & 53,828 & 531 & $1 \%$ \\
2010 & 60,941 & 1,104 & $2 \%$ \\
2011 & 74,015 & 512 & $0.7 \%$ \\
2012 & 124,480 & 314 & $0.3 \%$ \\
2013 & 135,489 & 326 & $0.2 \%$ \\
2014 & 157,308 & 310 & $0.2 \%$ \\
2015 & 25,490 & 18 & $0.1 \%$ \\
\hline
\end{tabular}

All loans that were refunded (100\%) had no description accompanying them, and 67\% of refunded loans were deemed noncredible (zero bonus credit eligibility). Most refunds came from the agricultural, food and retail sectors, in line with the distribution of total loan requests, which is highest in these particular sectors. Similarly, refunded loans originated mostly from Africa, Asia and Central America. But, in relative terms, the greatest proportion of refunded loans was from North America (1\%), despite the small number of loan requests from this region. Central America also appeared to be associated with an unexpectedly high amount of refunded loans, given the probability distributions of loans and refunds. Furthermore, Asia was relatively immune from refunds as 35\% of all loan requests originated from there but refunds affected Africa more than Asia.

\section{Conclusion and Further Study}

In an economic climate where it is very difficult for small and medium enterprises to source finance, and particularly for start-up projects, crowdfunding presents a viable alternative to seeking funding from angel investors. The main risks associated with crowdfunding are fraud (the money is not used for the declared aim), loss due to project failure, lack of liquidity, exchange rate fluctuations and operational risk. For the crowdfunding process to be completed successfully, the project needs 
to be attractive enough to gather the required funding prior to the expiration date, entrepreneurs need to abide by all of the platform's regulations to avoid being expelled, and they must repay their loans in accordance with the agreement made with lenders, on time and in full.

The example of Kiva teaches us how complex the crowdfunding process can be from an operational standpoint and how a project's minor characteristics may affect its attractiveness visà-vis investors, as well as the probability of a default. The attractiveness of a project is a topic of interest to entrepreneurs, marketers, crowdfunding platforms and their partners. The successful repayment of the loan is of greater interest to the lenders' side but also to crowdfunding platforms and their partners. To date, some authors have attempted to shed light on these topics (e.g., Ahlers et al., 2015; Allison et al., 2015; Allison et al., 2013; Bajde, 2013; Chen, 2015; Galak, Small, and Stephen, 2011; Kshetri, 2015; Meer and Rigbi, 2011; Mollick, 2014; Moss et al., 2015). Some of the questions that have been addressed revolve around project characteristics that increase the probability of funding, as well as the speed of funding. However, the results have been mixed and sometimes contradictory, which should encourage more researchers to tackle the topic of crowdfunding and explore its academic and practitioner-related issues.

From our side, this report serves as the foreground to our academic work on crowdfunding. We seek to unravel new and deeper insights, both theoretical and empirical, and to identify the factors behind crowdfunding success in the distinct contexts of entrepreneurship and charity (Moleskis, Alegre, and Canela, 2016). We hope our work proves useful for academics, practitioners and policy-makers. 


\section{References}

Ahlers, G. K. C., D. Cumming, C. Günther, and D. Schweizer (2015), "Signaling in Equity Crowdfunding." Entrepreneurship: Theory and Practice 39(4), pp. 955-980. doi: 10.1111/etap.12157.

Allison, T. H., B. C. Davis, J. C. Short, and J. W. Webb (2015), "Crowdfunding in a Prosocial Microlending Environment: Examining the Role of Intrinsic Versus Extrinsic Cues." Entrepreneurship: Theory and Practice 39(1), pp. 53-73. doi: 10.1111/etap.12108.

Allison, T. H., A. F. McKenny, and J. C. Short (2013), “The Effect of Entrepreneurial Rhetoric on Microlending Investment: An Examination of the Warm-Glow Effect." Journal of Business Venturing 28(6), pp. 690-707. doi: 10.1016/j.jbusvent.2013.01.003.

Bajde, D. (2013), “Marketized Philanthropy: Kiva's Utopian Ideology of Entrepreneurial Philanthropy.” Marketing Theory 13(1), pp. 3-18. doi: 10.1177/1470593112467265.

Chen, R., Y. Chen, Y. Liu, and Q. Mei (2015), "Does Team Competition Increase Pro-Social Lending? Evidence From Online Microfinance.” Forthcoming in Games and Economic Behavior.

Galak, J., D. Small, and A. T. Stephen (2011), "Microfinance Decision Making: A Field Study of Prosocial Lending." Journal of Marketing Research, 48, S130-S137. doi: 10.1509/jmkr.48.SPL.S130.

Hartley, S. (2010), "Kiva.org: Crowd-Sourced Microfinance \& Cooperation in Group Lending." Retrieved from https://dash.harvard.edu/handle/1/3757699.

Kshetri, N. (2015), "Success of Crowd-Based Online Technology in Fundraising: An Institutional Perspective." Journal of International Management 21(2), pp. 100-116. doi: 10.1016/j.intman.2015.03.004.

Massolution (2015), 2015CF: Crowdfunding Industry Report. Retrieved from: http://www.crowdsourcing.org/editorial/global-crowdfunding-market-to-reach-344b-in-2015predicts-massolutions-2015cf-industry-report/45376.

Meer, J., and 0. Rigbi (2011), "Transactions Costs and Social Distance in Philanthropy: Evidence from a Field Experiment."

Moleskis, M., I. Alegre, and M. A. Canela (2016), “Attraction of Funding in Hybrid Organizations: Charity or Venture Capitalism?” Working paper.

Mollick, E. (2014), “The Dynamics of Crowdfunding: An Exploratory Study.” Journal of Business Venturing, 29(1), pp. 1-16. doi: 10.1016/j.jbusvent.2013.06.005.

Moss, T. W., D. O. Neubaum, and M. Meyskens (2015), "The Effect of Virtuous and Entrepreneurial Orientations on Microfinance Lending and Repayment: A Signaling Theory Perspective." Entrepreneurship: Theory and Practice, 39(1), pp. 27-52. doi: 10.1111/etap.12110.

Nolan, D., and D. Temple Lang (2014), XML and Web Technologies for Data Sciences With $R$. Springer, New York. 